\title{
CARRAGEENAN ENHANCES CHONDROGENESIS AND OSTEOGENESIS IN HUMAN BONE MARROW STEM CELL CULTURE
}

\author{
V. Graceffa ${ }^{1,2}$ and D.I. Zeugolis ${ }^{1,2, *}$ \\ ${ }^{1}$ Regenerative, Modular and Developmental Engineering Laboratory (REMODEL), Biomedical Sciences \\ Building, National University of Ireland Galway (NUI Galway), Galway, Ireland \\ ${ }^{2}$ Science Foundation Ireland (SFI) Centre for Research in Medical Devices (CÚRAM), Biomedical Sciences \\ Building, National University of Ireland Galway (NUI Galway), Galway, Ireland
}

\begin{abstract}
The extracellular matrix is a dynamic and active component of the mesenchymal stem cell niche, which controls their differentiation and self-renewal. Traditional in vitro culture systems are not able to mimic matrix-cell interactions due to the small amount of extracellular matrix present. Macromolecular crowding, a biophysical phenomenon based on the excluded-volume effect, dramatically accelerates and increases tissue-specific extracellular matrix deposition during in vitro culture. Herein, the influence of macromolecular crowding in pre-condition and tri-lineage differentiation of human bone marrow mesenchymal stem cells was investigated. Carrageenan, a sulphated polysaccharide, enhanced chondrogenesis, as evidenced by increased collagen type II and chondroitin sulphate deposition and unaffected Sox-9 expression. Osteogenesis was also enhanced when carrageenan was used only in the differentiation phase, as evidenced by increased mineralisation, collagen type I deposition and osteopontin expression. Adipogenesis was not enhanced in the presence of carrageenan, suggesting that the chemistry of the crowder may affect stem-cell-lineage commitment. In conclusion, carrageenan, a sulphated polysaccharide, enhanced extracellular matrix deposition and promoted chondrogenesis and osteogenesis but not adipogenesis in human bone marrow mesenchymal stem cell cultures.
\end{abstract}

Keywords: Bone marrow mesenchymal stem cells, macromolecular crowding, extracellular matrix, stem cell pre-conditioning, tri-lineage differentiation.

*Address for correspondence: D.I. Zeugolis, Biomedical Sciences Building, National University of Ireland Galway (NUI Galway), Galway, Ireland.

Telephone number: +35391493166Ｅmail: dimitrios.zeugolis@nuigalway.ie

Copyright policy: This article is distributed in accordance with Creative Commons Attribution Licence (http://creativecommons.org/licenses/by-sa/4.0/).

\section{Introduction}

In vivo, the fate of mesenchymal stem cells is controlled by a reciprocal interaction with the surrounding extracellular matrix (ECM). The ECM regulates several cell functions, including attachment, shape, migration and differentiation (Ahmed and Ffrench-Constant, 2016; Gattazzo et al., 2014; Guilak et al., 2009; Kim et al., 2011) and, in response to these signals, cells appropriately remodel the surrounding matrix (Hoshiba et al., 2009; Hoshiba et al., 2010). ECM remodelling that accompanies cell differentiation directly controls stem cell behaviour and fate (Crane and Cao, 2014; Gattazzo et al., 2014; Lu et al., 2011). In vitro, the ECM also controls cell functions and triggers cell differentiation, even in the absence of exogenous inducing factors (Mao et al., 2017; Rao Pattabhi et al., 2014; Tang et al., 2013; Thibault et al., 2010; Young et al., 2013). This is not surprising considering that the ECM presents a multitude of biochemical, biophysical and biological cues in the stem cell niche that modulate their fate and function (Smith and Gerecht, 2018; Watt and Huck, 2013).

Applications of stem cells sheets are emerging as therapeutic strategies for the treatment of different injuries and pathophysiologies (Graceffa et al., 2018; Luo and Chen, 2018; Miyagawa et al., 2017; Pagani et al., 2003; Pellegrini et al., 1997; Sawa et al., 2012). Bone marrow mesenchymal stem cell (BMSC) sheets have been developed and characterised in vitro (Goldberg et al., 2017; See et al., 2010; Solorio et al., 2012) and assessed in pre-clinical models (Itokazu et al., 2016; 
Ma et al., 2017; Yano et al., 2013; Zou et al., 2009) for a wide range of clinical indications, including fat (Aubin et al., 2015; D'Andrea et al., 2008; Labbe et al., 2011; Vermette et al., 2007), bone (Geng et al., 2013; Goldberg et al., 2017; Ma et al., 2017; Wang et al., 2017; Zou et al., 2009) and cartilage (Ge et al., 2016; Itokazu et al., 2016; Qi et al., 2014; Solorio et al., 2012; Yano et al., 2013) tissue regeneration. However, due to slow and low level of ECM deposition, prolonged culture time is required to develop a scaffold-free implantable device [e.g. 14-21 d for corneal epithelium (Tsai et al., 2000), 25-50 d for skin (Cantin-Warren et al., 2018), 196 d for blood vessel (L'Heureux et al., 2006)], which is usually associated with cell phenotypic drift (Cigognini et al., 2013). Further, it is generally recognised that in vitro induction is necessary prior to implantation to ensure uniform differentiation and avoid unwanted differentiation, uncontrolled proliferation and senescence (He et al., 2017; Heng et al., 2004; Herberts et al., 2011; Lepperdinger et al., 2008; Trombi et al., 2016; Yorukoglu et al., 2017; Young et al., 2013). Decellularised stem, permanently differentiated and immortalised cell-derived matrices are traditionally used to either support efficient stem cell expansion or to direct stem cells towards a specific lineage (Cheng et al., 2014; Fitzpatrick and McDevitt, 2015; Harris et al., 2018; Kaukonen et al., 2017; Kusuma et al., 2017). However, again due to slow and low level of ECM deposition in traditional in vitro systems, among others, cell-ECM interactions and interconnectivity are not mimicked, leading to less and often uncontrollable differentiation/unwanted trans-differentiation (Choi et al., 2012; Huang et al., 2017; Kwon et al., 2013; Marinkovic et al., 2016).

Macromolecular crowding (MMC) is a bioinspired in vitro technique based on the fact that the extracellular space is a highly crowded milieu, as no individual macromolecule is present at high concentration (Minton, 1997; Minton, 2000). MMC consists of the addition of inert macromolecules to the culture medium, which, by occupying a substantial part of the available volume (excluding volume effect), accelerate enzymatic reactions (including the rate-limited conversion of pro-collagen to collagen), biological processes and macromolecular associations (Chen et al., 2011; Minton, 1993). MMC enhances and accelerates, in general granular (Benny et al., 2015; Lareu et al., 2007b), ECM deposition in permanently differentiated cell cultures; an up to 120-fold increase in ECM deposition has been documented within $48 \mathrm{~h}$ of crowded culture, whilst traditional non-crowded systems require several weeks to months for the development of cell sheets with similar amounts of ECM (Benny et al., 2015; Chen et al., 2009; Kumar et al., 2015a; Kumar et al., 2015b; Lareu et al., 2007a; Lareu et al., 2007b; Magno et al., 2017; Peng et al., 2012; Rashid et al., 2014; Satyam et al., 2014).

MMC (with polyvinylpyrrolidone $360 \mathrm{kDa}$ ) in human BMSC cultures enhances extracellular matrix deposition and cell proliferation (Rashid et al., 2014). Crowding with Ficoll ${ }^{\mathrm{TM}} 70 \mathrm{kDa}$ and
Ficoll $^{\mathrm{TM}} 400$ kDa cocktail in human BMSC cultures increases ECM deposition, induces supramolecular assembly and prompts ECM and intracellular actin cytoskeleton alignment (Zeiger et al., 2012). When carrageenan is used in pre-culture but not during differentiation of human BMSCs, ECM deposition and chondrogenic differentiation are increased, adipogenic differentiation is decreased and osteogenic differentiation is not affected (Cigognini et al., 2016). Decellularised BMSC matrices produced under MMC (with Ficoll ${ }^{\mathrm{TM}} 70 \mathrm{kDa}$, Ficoll ${ }^{\mathrm{TM}} 400 \mathrm{kDa}$ and dextran sulphate $10 \mathrm{kDa}$ cocktail) conditions generate functional stem cell niches able to maintain and expand human haematopoietic stem and progenitor cells in vitro (Prewitz et al., 2015). When MMC (with Ficoll $^{\mathrm{TM}} 70 \mathrm{kDa}$ and Ficoll ${ }^{\mathrm{TM}} 400 \mathrm{kDa}$ cocktail) is used in chemically induced adipogenesis, it significantly enhances the adipogenic differentiation of human BMSCs (Ang et al., 2014) and induces browning in human BMSC-derived white adipocytes (Lee et al., 2016). However, neither of these studies assessed the influence of MMC on chondrogenic and osteogenic differentiation and MMC pre-conditioning was not used. In human adipose-derived stem cell (ADSC) cultures, osteogenic and adipogenic differentiation are enhanced, whilst chondrogenic differentiation is reduced under MMC (with Ficoll ${ }^{\mathrm{TM}} 70 \mathrm{kDa}$ and Ficoll $^{\mathrm{TM}} 400 \mathrm{kDa}$ cocktail) conditions (Patrikoski et al., 2017). Considering that numerous studies have demonstrated the beneficial effects of various pre-conditioning factors (e.g. oxygen tension, medium supplementation, mechanical or electrical stimulation, far-infrared irradiation, scaffolds) on stem cell function and lineage commitment (George et al., 2017; Li et al., 2017; Licht et al., 2016; Lin et al., 2017; Wu et al., 2016; Zhang et al., 2015), the present study ventured to assess the influence of MMC pre-conditioning in human BMSC fate and lineage commitment. Specifically, human BMSCs were cultured in the absence or presence of MMC and, subsequently, differentiated towards chondrogenic, adipogenic and osteogenic lineage, again, in the absence or presence of MMC (Fig. 1).

\section{Materials and Methods}

\section{Materials}

Unless otherwise stated, chemicals and culture media were purchased from Sigma-Aldrich and tissue culture consumables from Sarstedt.

\section{Cell culture}

Human BMSCs were isolated from fresh bone marrow (2 male donors, 22 and 23 years old; Lonza) as previously described (Cigognini et al., 2016; Gaspar et al., 2018). Cells were expanded up to passage 4 in alpha-minimum essential medium $(\alpha$-MEM) with GlutaMAX ${ }^{\mathrm{TM}}$ (Gibco) supplemented with $10 \%$ foetal bovine serum (FBS). Cells at passage 5 were seeded at a density of 5,000 cells $/ \mathrm{cm}^{2} .1 \mathrm{~d}$ after seeding, MMC 


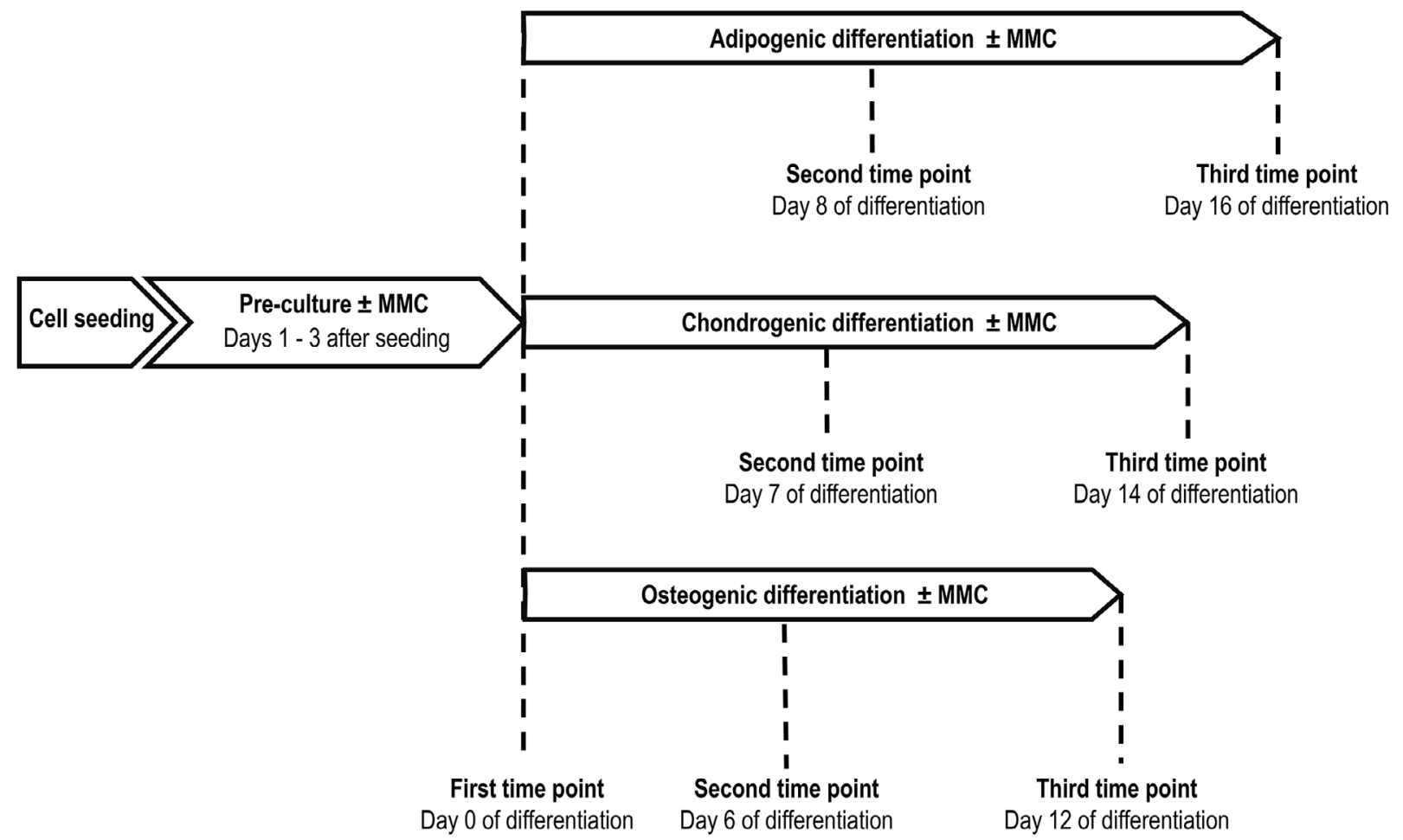

Fig. 1. Schematic workflow of the experiments. Cells were cultured with and without MMC and, then, differentiated into adipogenic, chondrogenic and osteogenic lineage with and without MMC. Deposited ECM and phenotypic markers were evaluated at the end of the MMC pre-culture (day 0 of differentiation), at day 8 and 16 of adipogenic induction, at day 7 and 14 of chondrogenic induction and at day 6 and 12 of osteogenic induction.

medium was added (culture medium supplemented with $100 \mu \mathrm{M}$ L-ascorbic acid 2-phosphate, with or without $100 \mu \mathrm{g} / \mathrm{mL}$ carrageenan). After $2 \mathrm{~d}$ of MMC, media were switched to chondrogenic, osteogenic or adipogenic induction media.

Adipogenesis was induced through cycles of $3 \mathrm{~d}$ of induction [Dulbecco's modified Eagle medium high glucose (DMEM-HG), supplemented with $10 \%$ FBS, $0.2 \mathrm{mM}$ indomethacin, $1 \mu \mathrm{M}$ dexamethasone, $0.5 \mathrm{mM}$ 3-isobutyl-1-methylxanthine (IBMX), $10 \mu \mathrm{g} /$ $\mathrm{mL}$ insulin, with or without $100 \mu \mathrm{g} / \mathrm{mL}$ carrageenan] and $1 \mathrm{~d}$ of maintenance (DMEM-HG, supplemented with $10 \% \mathrm{FBS}$ and $10 \mu \mathrm{g} / \mathrm{mL}$ insulin, with or without $100 \mu \mathrm{g} / \mathrm{mL}$ carrageenan). Chondrogenic medium consisted of DMEM-HG, supplemented with $10 \mathrm{ng} /$ $\mathrm{mL}$ transforming growth factor $\beta 3$ (TGF- $\beta 3$ ), $10 \mu \mathrm{M}$ dexamethasone, $10 \%$ insulin-transferrin-selenium (ITS), $1 \%$ sodium pyruvate, $100 \mu \mathrm{M}$ ascorbate, with or without $100 \mu \mathrm{g} / \mathrm{mL}$ carrageenan. Osteogenic medium consisted of DMEM low glucose (LG) supplemented with $10 \%$ FBS, $100 \mu \mathrm{M}$ ascorbate, $10 \mathrm{mM} \beta$-glycerophosphate, $100 \mu \mathrm{M}$ dexamethasone, with or without $100 \mu \mathrm{g} / \mathrm{mL}$ carrageenan. Deposited $\mathrm{ECM}$ and lineage-specific phenotypic markers were analysed at day 0 of the various lineage induction (end of the MMC pre-culture; day 3 in total, with $2 \mathrm{~d}$ under MMC), at day 7 and 14 for chondrogenic induction, day 8 ( 2 cycles) and 16 (4 cycles) for adipogenic induction and day 6 and 12 for osteogenic induction. The following abbreviations are used in the manuscript: $-/-$ samples pre-conditioned and differentiated without MMC; -/+ samples preconditioned without MMC and differentiated with MMC; +/- samples pre-conditioned with MMC and differentiated without MMC; +/+ samples preconditioned and differentiated with MMC.

\section{Collagen extraction and gel electrophoresis}

To determine the MMC pre-condition period, BMSCs were cultured for 2,4 and $7 \mathrm{~d}$ with and without MMC. Deposited collagen was evaluated through sodium dodecyl sulphate polyacrylamide gel electrophoresis (SDS-PAGE) and complementary densitometric analysis, as described previously (Capella-Monsonís et al., 2018). Briefly, collagen was isolated by incubation of the cell layer for $2 \mathrm{~h}$ at $37^{\circ} \mathrm{C}$ with $0.1 \mathrm{mg} / \mathrm{mL}$ porcine gastric mucosa pepsin in $0.05 \mathrm{M}$ acetic acid (ThermoFischer Scientific); samples were digested with $150 \mu \mathrm{L}$ of pepsin-acetic acid per well (24-well plate). The extracted collagen was neutralised with $1 \mathrm{M} \mathrm{NaOH}$ and mixed with loading buffer (4/5 of sample and $1 / 5$ of loading buffer $5 \times$ ). $15 \mu \mathrm{L}$ per well were loaded on to the gels. Bovine collagen type I (Symatese Biomateriaux, Chaponost, France) was loaded as control. Electrophoretic run was performed using the Mini-Protean ${ }^{\circledR} 3$ electrophoresis system (Bio-Rad Laboratories). The gels were stained using the SilverQuest ${ }^{\mathrm{TM}}$ kit (Invitrogen). To quantify the total amount of collagen, densities of collagen $\alpha 1$ and $\alpha 2$ chains were calculated using Image software 
(NIH) and the sum of the densities of $\alpha 1$ and $\alpha 2$ chains were correlated with the collagen standard.

\section{Cell metabolic activity}

alamarBlue ${ }^{\circledR}$ assay (BioSource International, Invitrogen) was used to evaluate cell metabolic activity. Cells were incubated with alamarBlue ${ }^{\circledR}$ solution [10\% alamarBlue ${ }^{\circledR}$ in Hanks' balanced salt solution (HBSS)] for $4 \mathrm{~h}$ at $37{ }^{\circ} \mathrm{C}$ and absorbances at $550 \mathrm{~nm}$ and $595 \mathrm{~nm}$ were measured using a Varioskan Flash spectral scanning multimode reader (ThermoFischer Scientific). Percent variations of alamarBlue $^{\circledR}$ reduced as compared to controls (non MMC conditions) were calculated.

\section{Cell viability}

Samples were washed with PBS and cell viability was evaluated using the Live/Dead ${ }^{\circledR}$ viability kit (Invitrogen). Fluorescence images were acquired using an Olympus IX81 inverted fluorescence microscope.

\section{Enzyme-linked immunosorbent assay (ELISA)}

Cell layers, harvested and lysed using radioimmunoprecipitation assay (RIPA) lysis buffer, were diluted 10 times in PBS. Acid activation of latent TGF- $\beta 1$ was performed by addition of $12 \mu \mathrm{L}$ of $4 \mathrm{M}$ $\mathrm{HCl}$ per $250 \mu \mathrm{L}$ of diluted samples and incubation for $1 \mathrm{~h}$ at $4{ }^{\circ} \mathrm{C}$ while shaking (Hawinkels et al., 2007; Lawrence et al., 1984). Before analysis, samples were neutralised by addition of $12 \mu \mathrm{L}$ of $4 \mathrm{M} \mathrm{NaOH}$. Samples were analysed using the human ELISA VEGF kit (PeproTech) and the TGF beta 1 ELISA Kit, Human (Abcam).
Glycosaminoglycan (GAG) and DNA quantification Cell layers and culture media were digested for $3 \mathrm{~h}$ at $60{ }^{\circ} \mathrm{C}$ with $0.1 \%$ crystallised papain in $0.2 \mathrm{M}$ sodium phosphate buffer $\mathrm{pH}$ 6.4, containing sodium acetate, ethylenediaminetetraacetic acid (EDTA), disodium salt and cysteine-HCl. For GAG quantification, Blyscan ${ }^{\mathrm{TM}}$ Glycosaminoglycan Assay (Biocolor, Carrickfergus, UK) was used. For DNA quantification, samples digested with papain were diluted 10 times in Tris-EDTA (TE) buffer and the Quant-iT ${ }^{\mathrm{TM}}$ PicoGreen ${ }^{\circledR}$ dsDNA Assay Kit was used.

\section{Immunocytochemistry}

Cells were fixed with $10 \%$ formalin or with icecold methanol (for intracellular staining). Primary antibodies for collagen type I (ab90395, Abcam), collagen type II (ab185430, Abcam), collagen type IV (ab6586, Abcam), collagen type X (ab49945, Abcam), osteopontin (ab69498, Abcam) and fatty acid binding protein 4 (FABP4, ab92501, Abcam) were incubated overnight at $4{ }^{\circ} \mathrm{C}$ in $3 \%$ bovine serum albumin (BSA) in PBS, at a concentration of $1: 200$. Secondary antibodies AlexaFluor488 donkey anti-mouse (A21202, Abcam) and AlexaFluor546 goat anti-rabbit (A11035, Abcam) were incubated for $1 \mathrm{~h}$ at room temperature, at a concentration of $1: 400$. Nuclei were counterstained using 4,6-diamidino- 2-phenylindole (DAPI, Invitrogen) and images were acquired using an Olympus IX-81 inverted fluorescence microscope. Mean fluorescence intensity per each microscope field ( $n=15$ per group) was calculated using ImageJ software and normalised for the average mean fluorescence intensity of negative controls (omission of primary antibody).

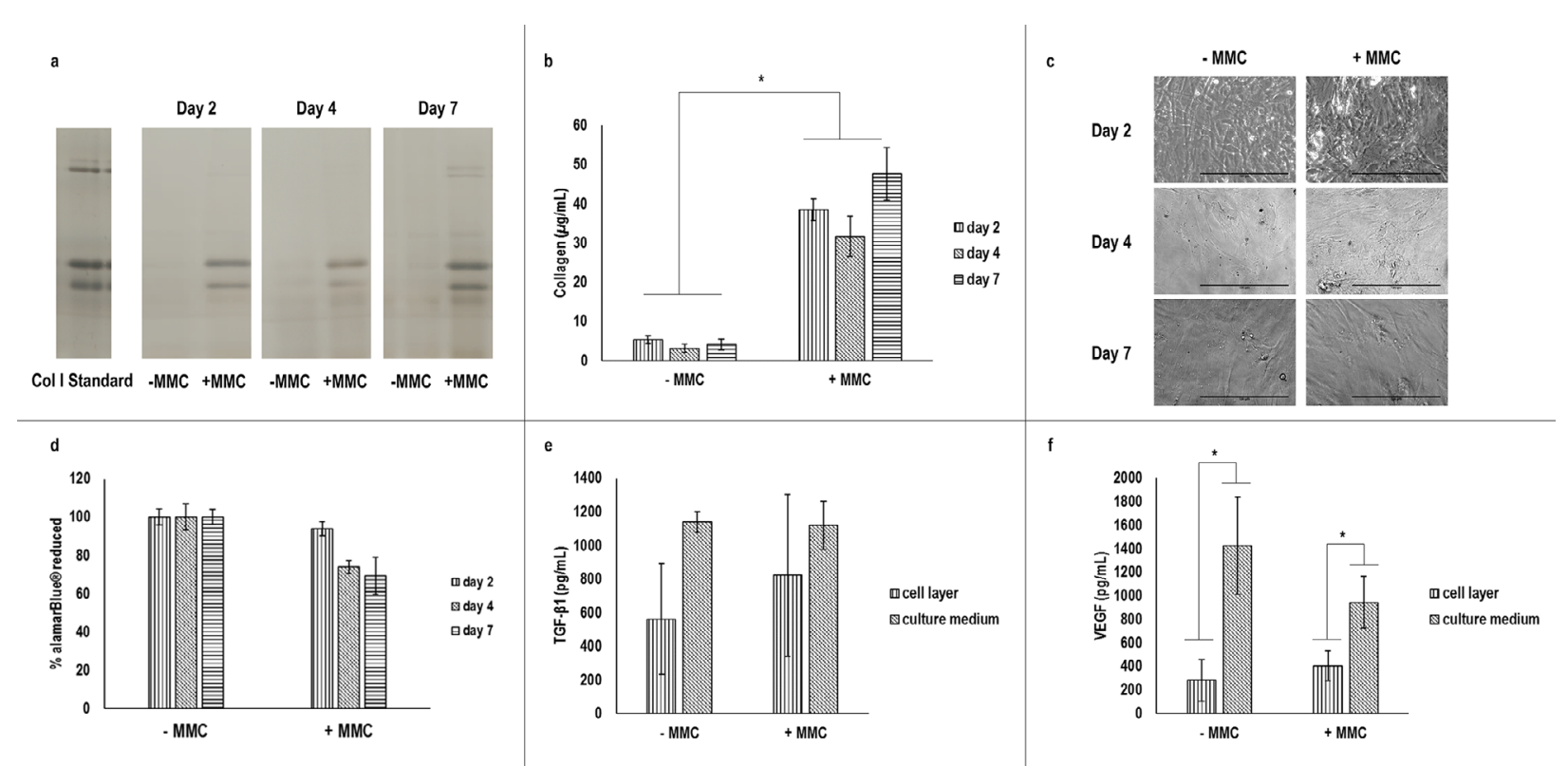

Fig. 2. Optimisation of MMC pre-culture. (a) SDS-PAGE and (b) relative quantification of collagen in the cell layer showed that $2 \mathrm{~d}$ of MMC were sufficient to increase collagen deposition and no substantial increase was observed at subsequent time points. (c) Cell morphology was not affected as a function of MMC. (d) Although the cell metabolic activity was reduced in the presence of MMC at day 4 and 7, the decrease was not statistically significant. After $2 \mathrm{~d}$ of culture, no significant differences in (e) TGF- $\beta 1$ and (f) VEGF concentration in cell layer and medium were observed between crowded and non-crowded counterparts. * indicates statically significant differences. 
Oil red $\mathrm{O}$ staining and quantification of uptake Samples were fixed for $10 \mathrm{~min}$ with $10 \%$ formalin and stained for $5 \mathrm{~min}$ with oil red $\mathrm{O}$ solution (oil red $\mathrm{O}$ $0.3 \%$ in isopropanol, diluted $3: 2$ in distilled water) at room temperature. Nuclei were counterstained with haematoxylin and images were acquired using an inverted microscope (Leica Microsystems). For quantification of oil red $\mathrm{O}$ staining, the dye was extracted pipetting $100 \%$ isopropanol over the surface of the wells. Then, the solution was centrifuged at $500 \times g$ for $2 \mathrm{~min}$ to remove debris and the absorbance was measured at $520 \mathrm{~nm}$ using a Varioskan Flash spectral scanning multimode reader (ThermoFisher Scientific).

\section{Western blot}

Cells were lysed and proteins were extracted using RIPA lysis buffer, containing cOmplete ${ }^{\mathrm{TM}}$ Protease Inhibitor Cocktail, EDTA-free. Protein concentration was quantified using the Pierce ${ }^{\mathrm{TM}}$ BCA Protein Assay Kit (ThermoFisher Scientific). $5 \mu \mathrm{g}$ of protein was loaded on to a $12 \%$ acrylamide gel and separated under reducing conditions (DL-Dithiothreitol $20 \%$ $\mathrm{vol} / \mathrm{vol}$ in sample buffer). Then, proteins were transferred to a nitrocellulose membrane, blocked with $5 \%$ skim milk in tris-buffered saline-Tween 20 (TBS-T) and incubated overnight at $4{ }^{\circ} \mathrm{C}$ with primary antibody for Sox-9 (sc-166505, Santa Cruz Biotechnology) and $\beta$-actin (ab8226, Abcam),

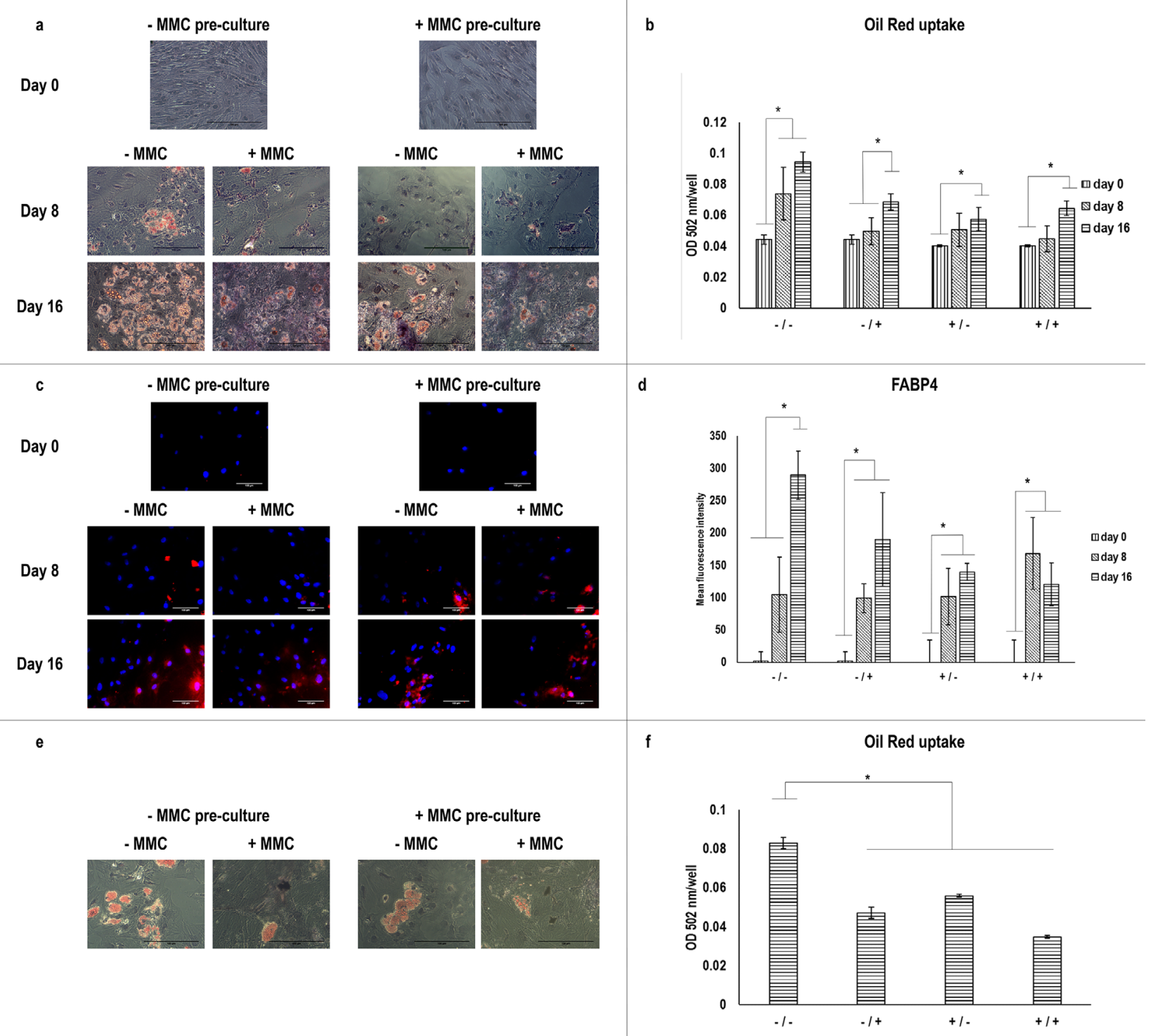

Fig. 3. Oil red staining and FABP4 immunocytochemistry analysis during adipogenic induction. (a) Oil red $\mathrm{O}$ staining and (b) complementary quantification uptake showed an increase in lipid droplets as a function of time in culture within each group and revealed that significantly more lipid droplets were accumulated when MMC was not used during the pre-condition and adipogenic differentiation phases $(-/-)$. FABP4 expression, as judged by (c) staining and (d) complementary fluorescence intensity analysis showed a tendency to increase as a function of time in culture within each group. When BMSCs were trypsinised at the end of the pre-condition phase and seeded in new wells for the adipogenic differentiation phase, (e) oil red O staining and (f) complementary quantification uptake revealed that more lipid droplets were accumulated when MMC was not used during the pre-condition and adipogenic differentiation phases (-/-), after day 16 of differentiation. * indicates statically significant difference. Scale bars: $100 \mu \mathrm{m}$. 
a

- MMC pre-culture

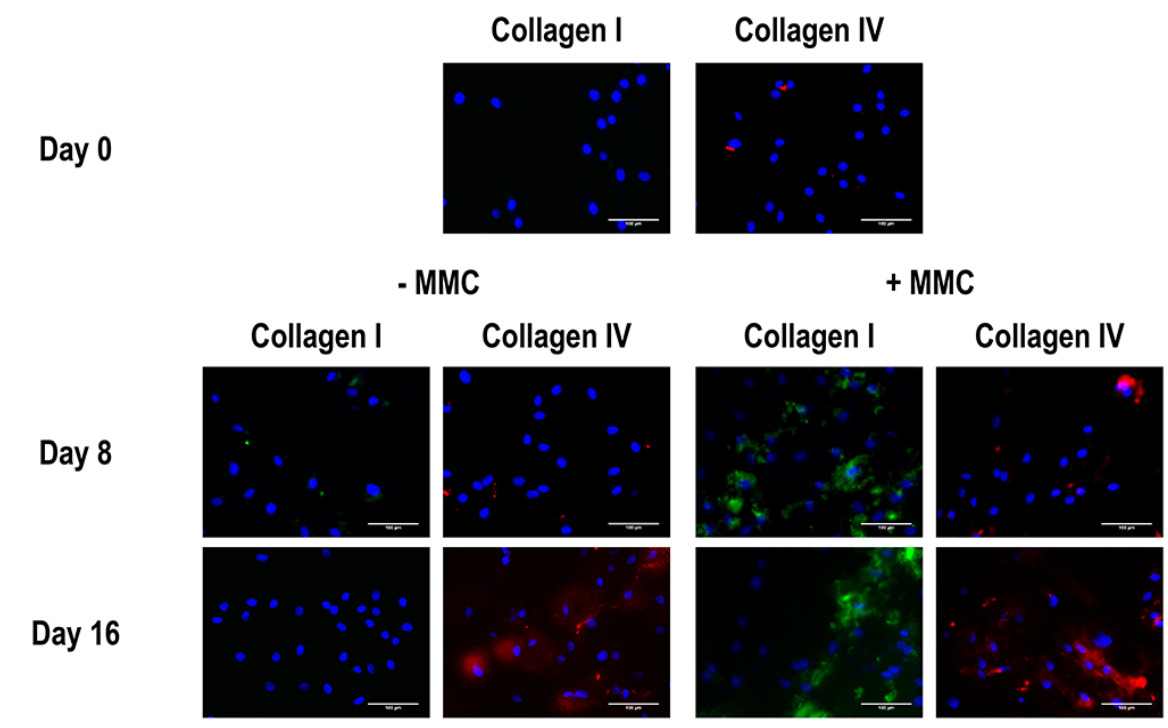

+ MMC pre-culture

Day 0
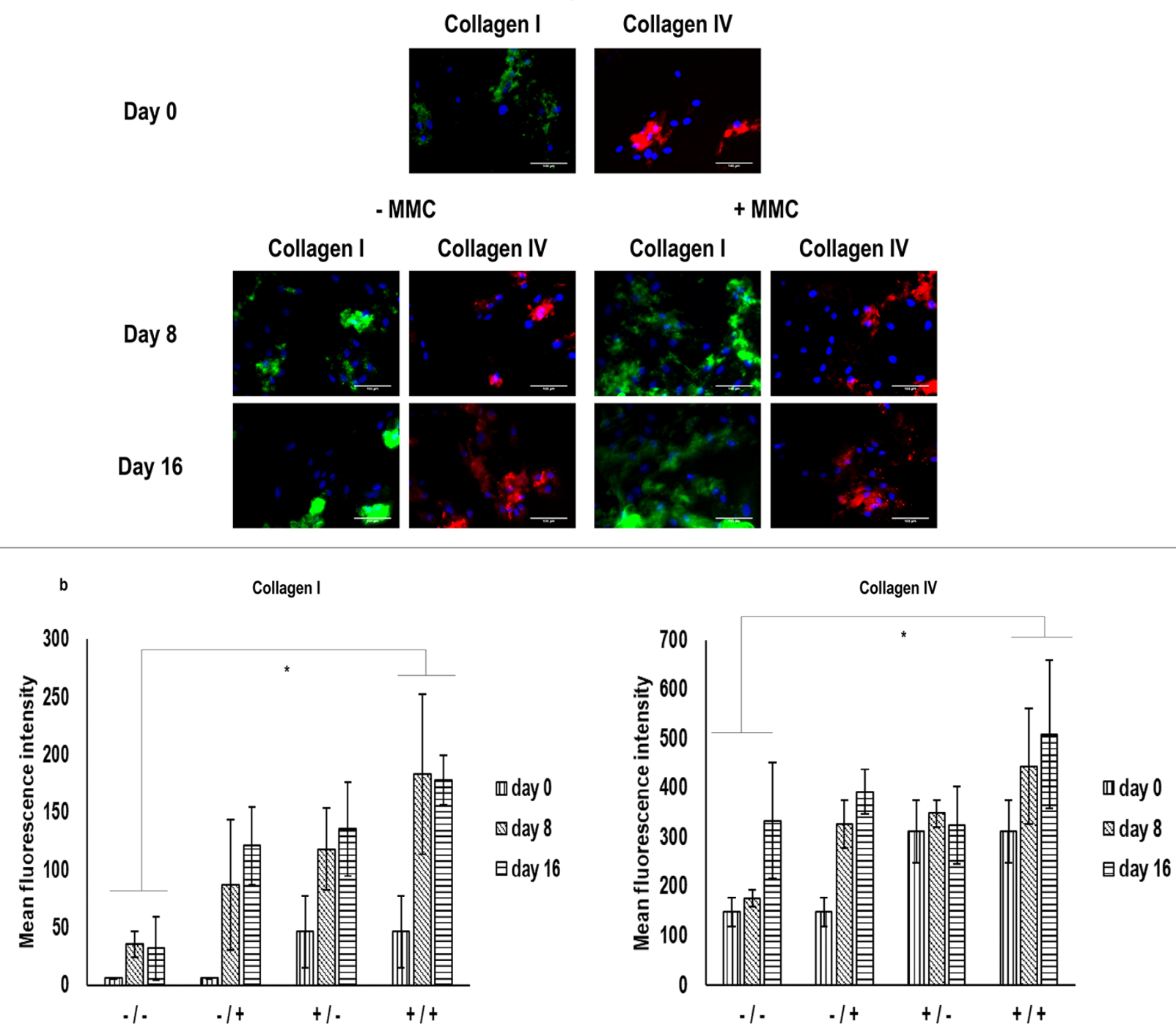

Fig. 4. Collagen type I and collagen type IV immunocytochemistry analysis during adipogenic induction. (a) Immunocytochemistry and (b) complementary image intensity analysis revealed that the highest, in comparison to -/- group, collagen type I and collagen type IV deposition was observed for the $+/+$ group at day 8 and 16. ${ }^{*}$ indicates statically significant difference. Scale bars: $100 \mu \mathrm{m}$. 
a

Day 0

Day 16

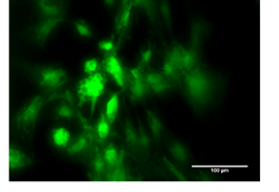

- MMC

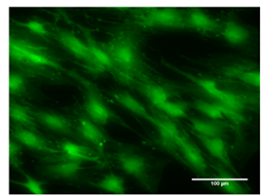

Day 8
- MMC pre-culture

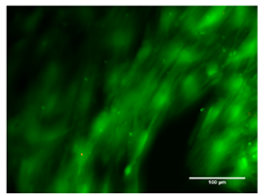

b

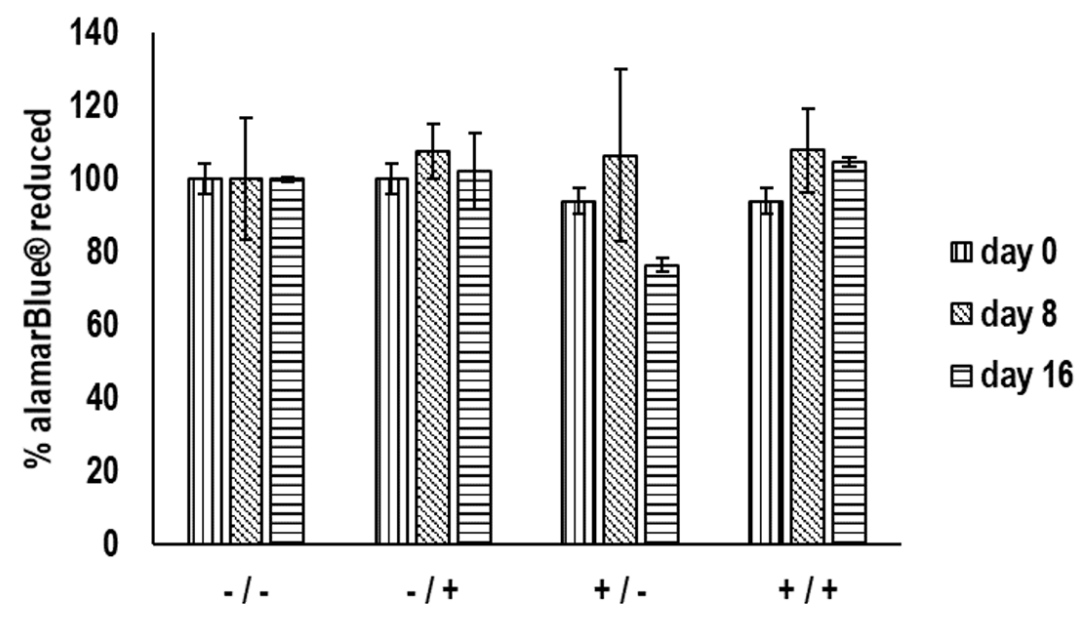

C

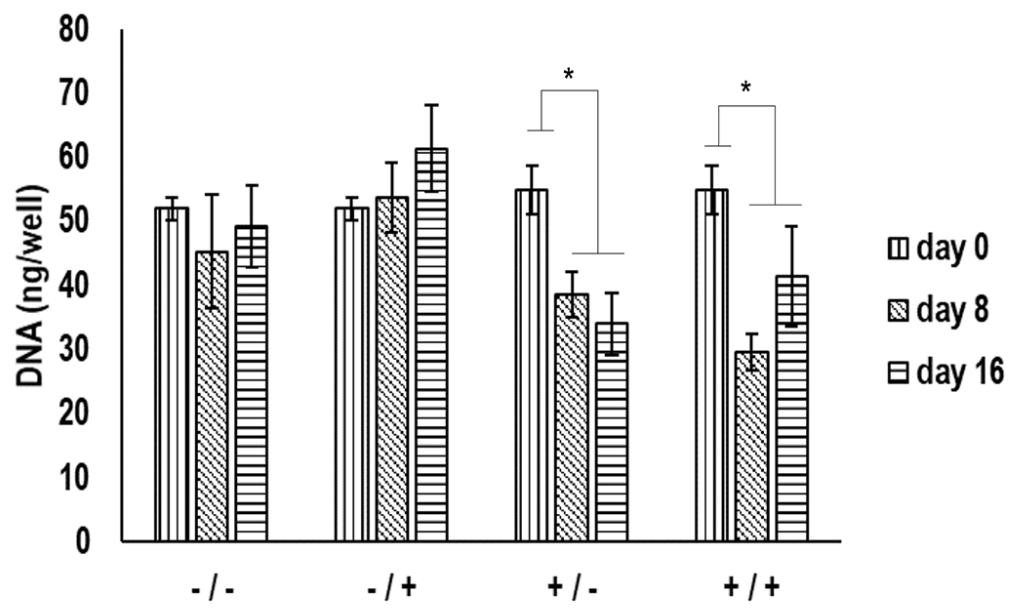

Fig. 5. Cell viability, metabolic activity and DNA content during adipogenic induction. (a) Cell viability, (b) metabolic activity and (c) DNA content were not affected for cells that were pre-conditioned in the absence of MMC prior to adipogenic differentiation $(-/-$ and $-/+)$, whilst a reduced DNA content was observed at day 8 and 16 for cells that were pre-conditioned in the presence of MMC (+/- and $+/+)$. ${ }^{*}$ indicates statically significant difference. Scale bars: $100 \mu \mathrm{m}$. 
a

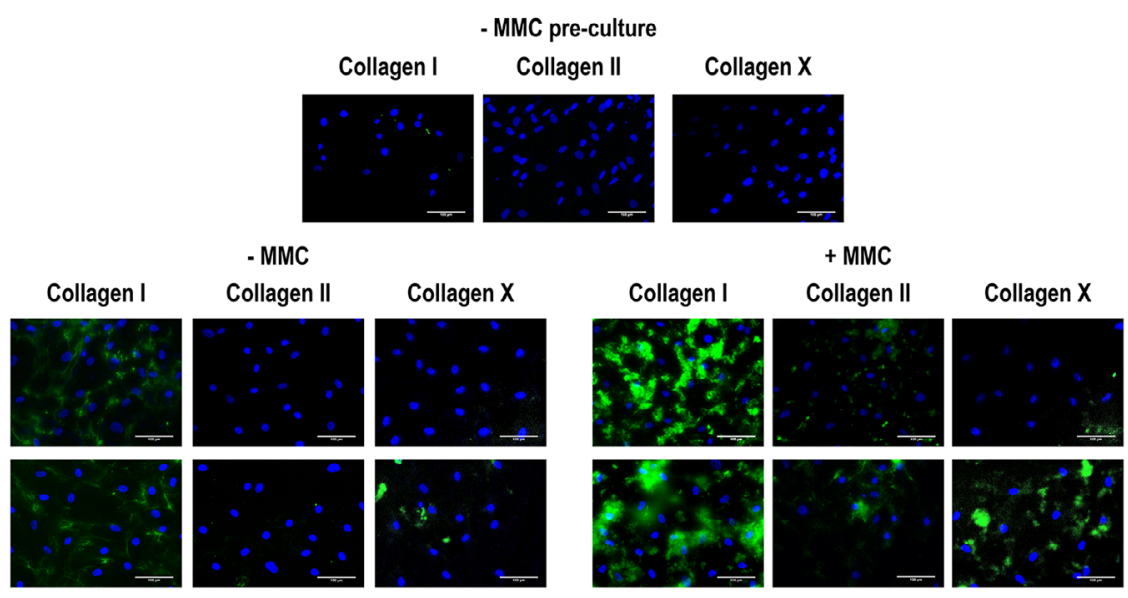

Day 0

Day 14

Day 7

+ MMC pre-culture

Collagen I Collagen II

Collagen $X$

Day 0
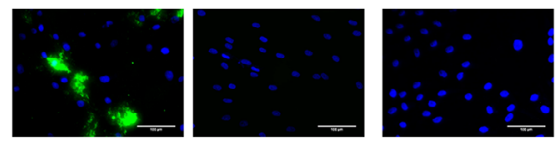

- MMC

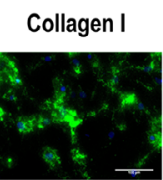

Collagen II
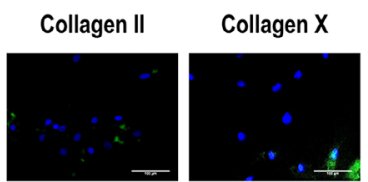

Collagen I

+ MMC

Day 7

Day 14
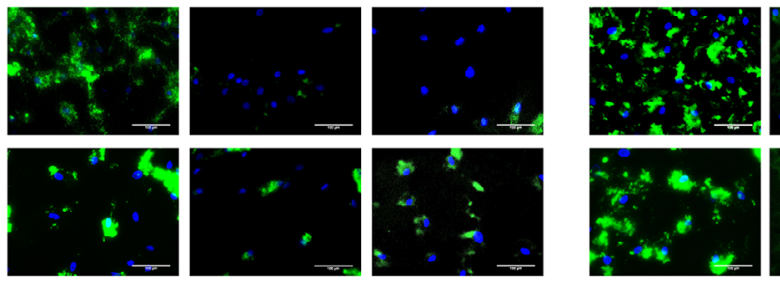

Collagen II

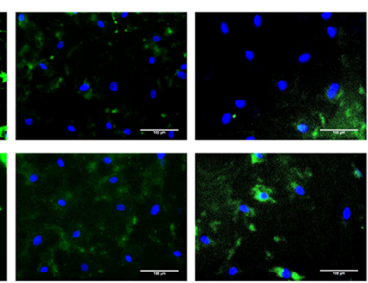

b

Collagen I

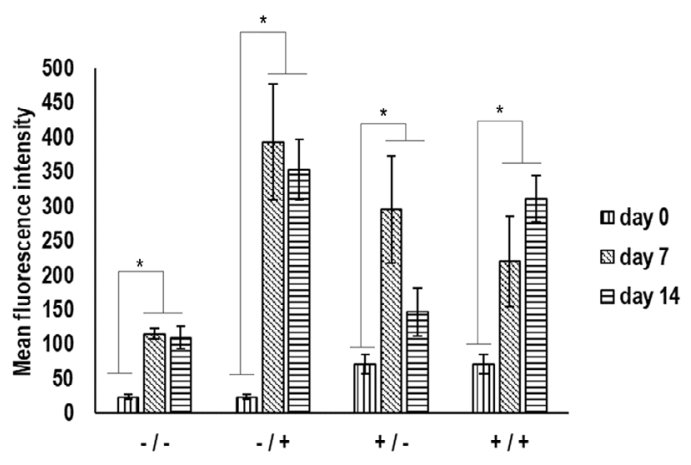

Collagen II

Collagen $X$
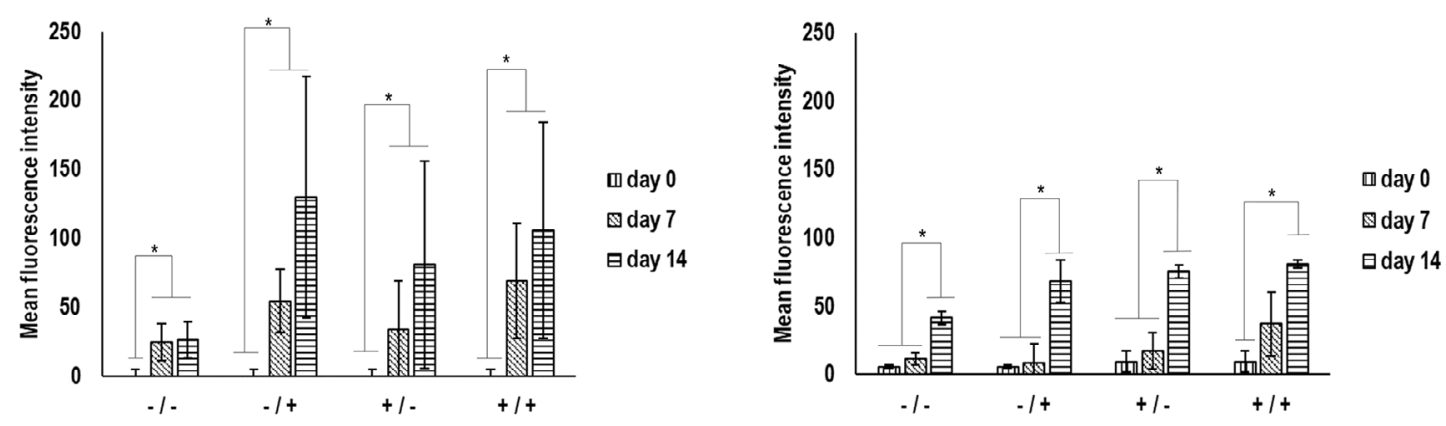

Fig. 6. Collagen type I, collagen type II and collagen type $X$ immunocytochemistry analysis during chondrogenic induction. (a) Immunocytochemistry and (b) complementary image intensity analysis revealed that, at day 7 and 14 , the MMC-crowded groups $(-/+,+/-$ and $+/+)$ exhibited significantly more $(p<0.05)$ collagen type I and II deposition than the non-MMC-crowded group $(-/-)$. A significant increase $(p<0.05)$ in collagen type $\mathrm{X}$ deposition for the MMC groups $(-/+,+/-$ and $+/+)$ over the non-MMC groups $(-/-)$ was only observed at day 14 and 7 for the $+/+$ group. ${ }^{*}$ indicates statically significant difference. Scale bars: $100 \mu \mathrm{m}$. 
diluted $1: 100$ and $1: 5,000$, respectively. Secondary antibody goat anti-mouse (31430, ThermoFisher Scientific) conjugated with horseradish peroxidase was incubated for $1 \mathrm{~h}$ at room temperature at $1: 10,000$ dilution. Bound antibodies were detected using SuperSignal ${ }^{\mathrm{TM}}$ West Pico Chemiluminescent Substrate (ThermoFisher Scientific).

\section{Alizarin red staining}

Samples were fixed with ice-cold methanol for $10 \mathrm{~min}$, stained with $0.2 \%$ alizarin red in water for $5 \mathrm{~min}$ and washed with water. Images were acquired using an inverted microscope (Leica Microsystems).

\section{Calcium quantification}

Samples were digested overnight at $4{ }^{\circ} \mathrm{C}$ with $0.5 \mathrm{M}$ $\mathrm{HCl}$. Calcium quantification was performed using the StanBio Calcium Liquicolour ${ }^{\mathrm{TM}}$ Kit. Absorbance at $550 \mathrm{~nm}$ was measured using the Varioskan Flash spectral scanning multimode reader (ThermoFisher Scientific) and amount of calcium per well was calculated using calcium standards.

\begin{abstract}
Alkaline phosphatase (ALP) activity
ALP activity was measured with slight modifications on the protocol described by Thibault et al. (2010). Briefly, cells were lysed with water $(200 \mu \mathrm{L} /$ well in a 24-well plate) and freeze-thawed at $-80{ }^{\circ} \mathrm{C}$ and room temperature twice, to release ALP. $20 \mu \mathrm{L}$ of the lysate were incubated with $80 \mu \mathrm{L}$ of $1-$ Step $^{\mathrm{TM}}$ PNPP Substrate Solution (37621, ThermoFisher Scientific) and, after $30 \mathrm{~min}$ of incubation at $37^{\circ} \mathrm{C}$, the reaction was stopped by addition of $100 \mu \mathrm{L}$ $0.05 \mathrm{M} \mathrm{NaOH}$. Absorbance at $405 \mathrm{~nm}$ was measured using a Varioskan Flash spectral scanning multimode reader (ThermoFisher Scientific). The amount of p-nitrophenol was calculated using p-nitrophenol standards and units of enzyme were calculated dividing the $\mu$ moles of p-nitrophenol produced by the time (min). DNA was quantified using the Quant-iT ${ }^{\mathrm{TM}}$ PicoGreen $^{\circledR}$ dsDNA Assay Kit and units of enzyme were normalised by the amount of DNA.
\end{abstract}

\section{Statistical analysis}

Unless otherwise stated, all experiments were conducted with two biological replicates and three technical replicates $(n=6)$. Statistical analysis was performed with Minitab version 17, Minitab Inc., USA. When the group distributions were normal (Anderson-Darling normality test) and variances of populations were equal (Bonett's test and Levene's test), one-way analysis of variance (Tukey's post-hoc test; for multiple comparisons) and 2-sample t-test (for pair wise comparisons) were performed. When group distributions were not normal, or variances were not equal, Kruskal-Wallis test was performed and Mann Whitney test was used as post-hoc. Results were considered statistically significant for $p<0.05$. Data are presented as mean \pm standard deviation (SD).

\section{Results}

\section{Optimisation of MMC pre-culture}

To optimise the length of MMC pre-conditioning, BMSCs were cultured for 2, 4 and $7 \mathrm{~d}$ under MMC and collagen deposition was evaluated by SDS-PAGE (Fig. 2a) and densitometric analysis (Fig. 2b). 2 d of MMC significantly $(p<0.001)$ increased collagen deposition and no significant $(p>0.05)$ increase was observed between day 2 and day 4 or 7. MMC did not appear to affect cell morphology (Fig. 2c). Although metabolic activity was not statistically reduced when MMC was used, it appeared to decrease from day 2 to day 4 and 7 (Fig. 2d). At day 2, independently of MMC use, sandwich ELISA showed no statistically significant difference $(p>0.05)$ in acid-activated TGF- $\beta 1$ (Fig. $2 \mathbf{e})$ between cell layers and culture media, whilst significantly larger $(p<0.001)$ amounts of vascular endothelial growth factor (VEGF) (Fig. 2f) were detected in culture media, as opposed to cell layers.

\section{Adipogenic induction}

Oil red $\mathrm{O}$ staining (Fig. 3a) and complementary quantification uptake (Fig. 3b) showed an increase in lipid droplets as a function of time in culture within each group and revealed that significantly more $(p<0.001)$ lipid droplets were accumulated after $16 \mathrm{~d}$ of adipogenic differentiation, independently of whether MMC was used in pre-condition or differentiation phase. FABP4 expression, as judged by immunofluorescent staining (Fig. 3c) and complementary fluorescence intensity analysis (Fig. 3d), was also increased from day 0 to day 8 or 18 for all groups; the highest expression was detected at day 16 for the -/- group.

When cells were trypsinised at the end of the pre-condition phase and seeded in new wells for the differentiation phase, the highest $(p<0.001)$ adipogenic potential at day 16 , as judged by oil red $O$ staining (Fig. 3e) and complementary quantification uptake (Fig. 3f), was observed for the -/- group.

Immunocytochemistry (Fig. 4a) and complementary image intensity analysis (Fig. 4b) revealed that the $+/+$ group exhibited significantly higher $(p<0.001)$ collagen type I and collagen type IV deposition than the $-/-$ group at day 8 and 16 .

Cell viability (Fig. 5a) was not affected for any of the conditions. Cell metabolic activity (Fig. 5b) was only reduced, albeit not significantly, at day 16 for the $+/-$ group. A reduced DNA content (Fig. 5c) was observed at day 8 and 16 for the $+/-$ and $+/+$ groups.

\section{Chondrogenic induction}

Immunocytochemistry (Fig. 6a) and complementary image intensity analysis (Fig. 6b) revealed an increased collagen type I, II and X deposition as a function of time in culture for all groups. At day 7 and 14 , the $-/+,+/-$ and +/+ groups exhibited significantly higher $(p<0.05)$ collagen type I and II deposition than the $-/-$ group. A significant increase $(p<0.05)$ 
a

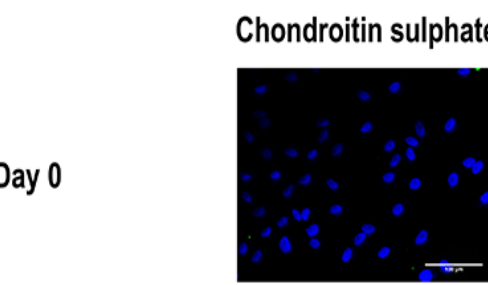

- MMC

Chondroitin sulphate Chondroitin sulphate

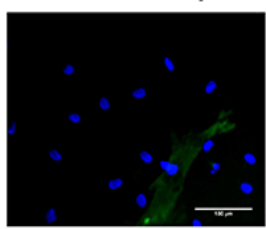

Day 7
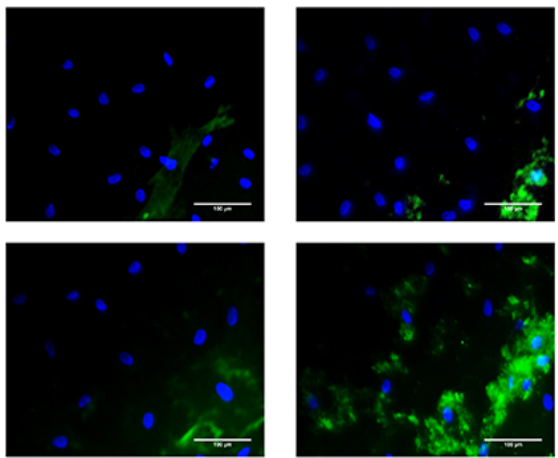

+ MMC pre-culture

Chondroitin sulphate

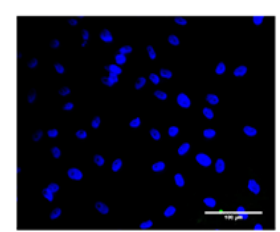

- MMC

Chondroitin sulphate Chondroitin sulphate
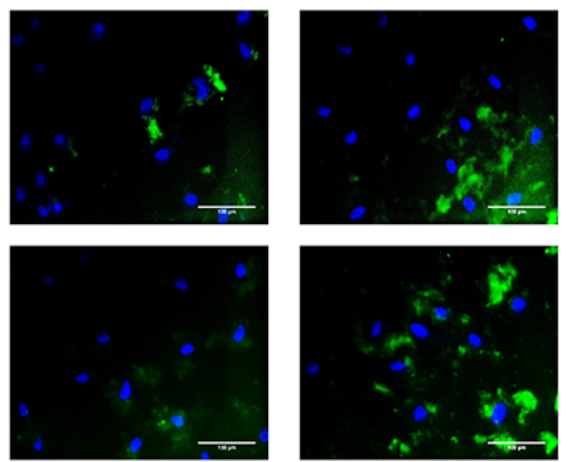

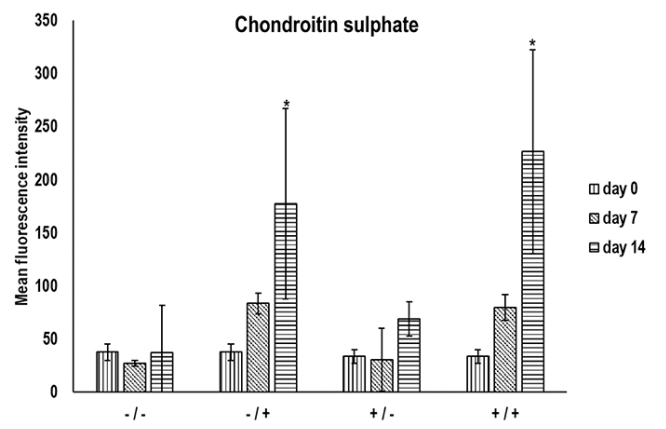

c

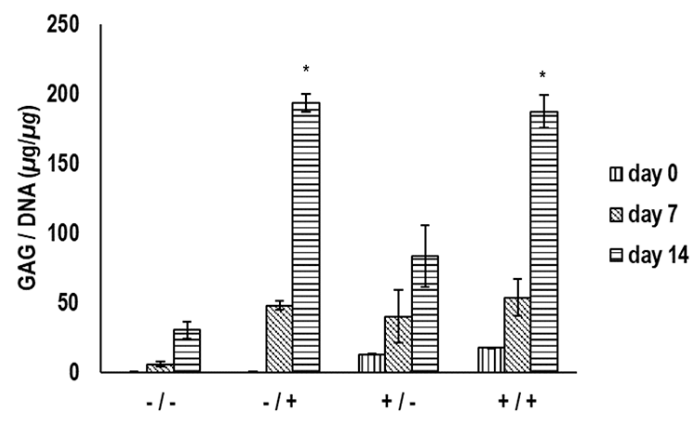

d
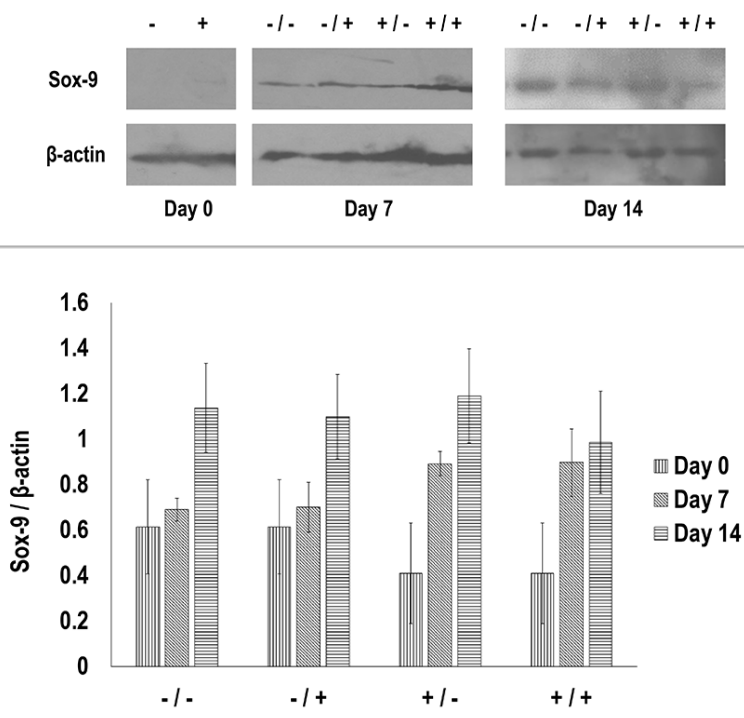

Fig. 7. Chondroitin sulphate immunocytochemistry, GAG content and Sox-9 western blot analysis during chondrogenic induction. (a) Immunocytochemistry and (b) complementary image intensity analysis revealed that the largest amount of chondroitin sulphate was deposited at day 14 from the $-/+$ or +/+ MMC-crowded groups. (c) Similar results were obtained when total GAG content per DNA was quantified. (d) Western blot and (e) densitometric analysis revealed no differences in Sox-9 expression between the groups at a given time point. ${ }^{*}$ indicates statically significant difference. Scale bars: $100 \mu \mathrm{m}$. 


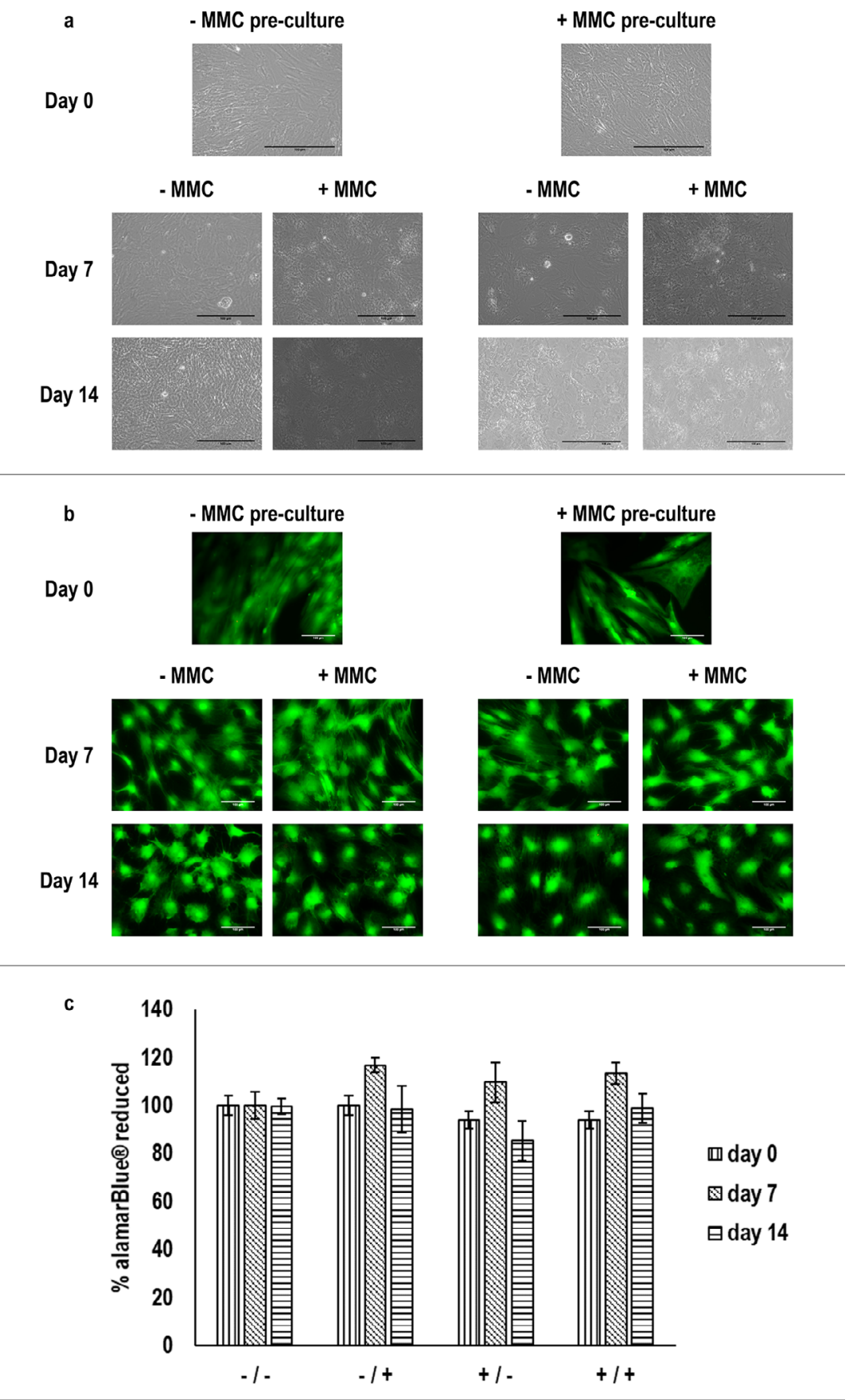

d

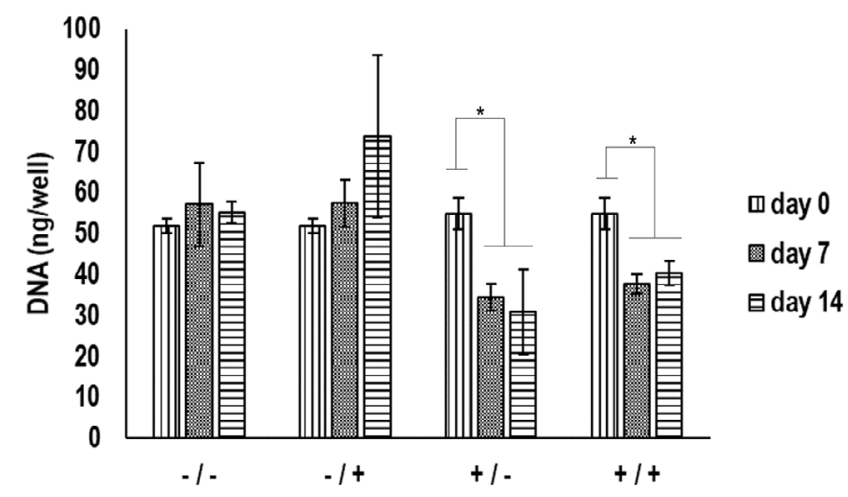

Fig. 8. Cell morphology, viability, metabolic activity and DNA content during chondrogenic induction. (a) Cell morphology, (b) viability and (c) metabolic activity were not affected for any of the groups. A reduced DNA content was observed at day 8 and 16 for cells that were pre-conditioned in the presence of MMC (+/- and +/+ groups). ${ }^{*}$ indicates statically significant difference. Scale bars: $100 \mu \mathrm{m}$. 
in collagen type $X$ deposition was only observed at day 7 and 14 for the $+/+$ group.

Immunocytochemistry (Fig. 7a) and complementary image intensity analysis (Fig. 7b) revealed that the highest $(p<0.001)$ amount of chondroitin sulphate was deposited at day 14 for the $-/+$ and +/+ groups. Similar results were obtained when total GAG content per DNA was quantified
(Fig. 7c). Western blot (Fig. 7d) and densitometric analysis (Fig. 7e) revealed no differences in Sox-9 expression among the groups at a given time point.

Cell morphology (Fig. 8a), viability (Fig. 8b) and metabolic activity (Fig. 8c) were not affected for any group. With respect to DNA content (Fig. $8 \mathrm{~d}$ ), a reduction was only observed at day 8 and day 16 for the $+/-$ and $+/+$ groups.
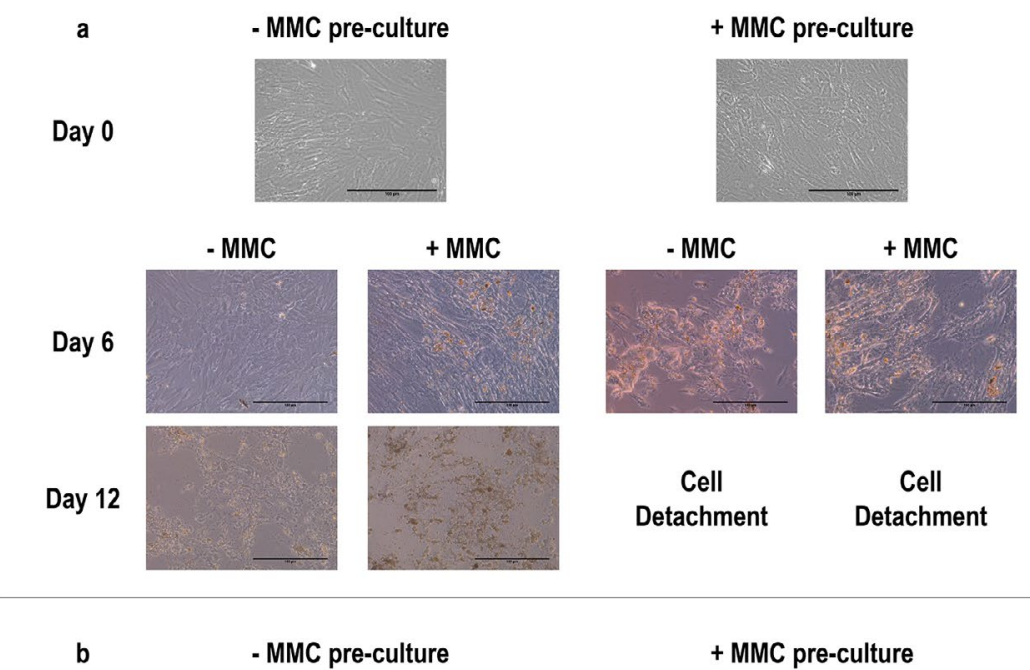

b - MMC pre-culture

+ MMC pre-culture
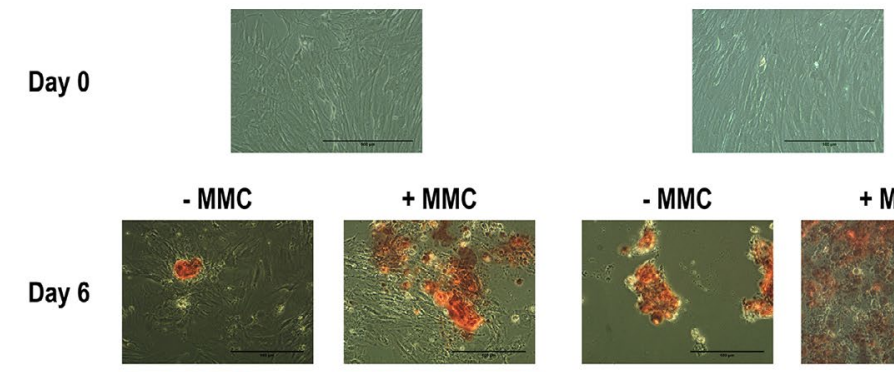

+ MMC
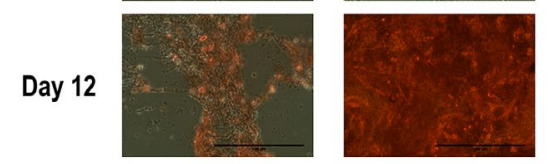

Cell

Detachment

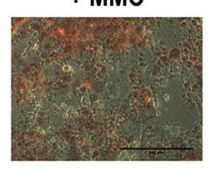

Cell Detachment

c

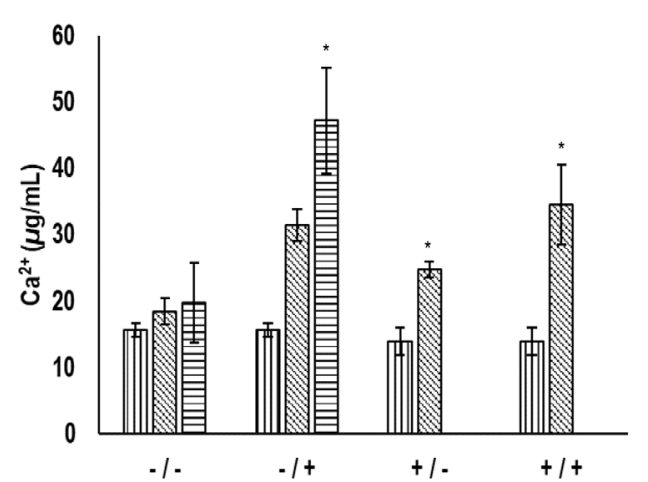

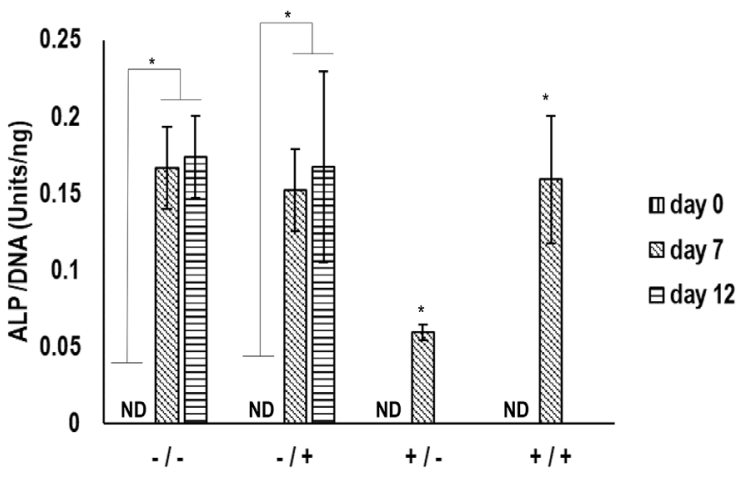

Fig. 9. Visual assessment, alizarin red staining, calcium content and ALP activity during osteogenic induction. (a) Gross visual assessment and (b) alizarin red staining revealed that MMC during the osteogenic differentiation phase $(-/+)$ increased mineralised areas and accumulated calcium nodules at day 6 and 12 . Increased mineralisation was observed at day 6 for the +/+ MMC-crowded group, but cell detachment prohibited the analysis at day 12. (c) The -/+ MMC-crowded group exhibited the highest calcium content after $12 \mathrm{~d}$ in culture. (d) Cells that were grown in the absence of MMC during the pre-condition phase and in the absence or presence of MMC during the differentiation phase (-/+ and +/+) exhibited similar ALP activity at respective time points. ${ }^{*}$ indicates statically significant difference. Scale bars: $100 \mu \mathrm{m}$. 


\section{Osteogenic induction}

Gross visual assessment (Fig. 9a) and alizarin red staining (Fig. 9b) revealed increased mineralised areas and accumulated calcium nodules at day 6 and 12 for the -/+ group and day 6 for the $+/+$ group (cell detachment prohibited analysis of the $+/+$ group at day 12). The $-/+$ group exhibited the highest $(p<0.001)$ calcium content after $12 \mathrm{~d}$ in culture (Fig. $9 c)$. The $-/-$ and $-/+$ groups exhibited similar ALP activity at respective time points and the $+/+$ group exhibited significantly higher ALP activity at day 6 than the +/- group (Fig. 9d).

Immunocytochemistry (Fig. 10a) and complementary image intensity analysis (Fig. 10b) revealed that the $-/+,+/-$ and $+/+$ groups deposited significantly more $(p<0.001)$ collagen type I than the -/- group. Further, immunocytochemistry (Fig. 10a) and complementary image intensity analysis (Fig. $10 b)$ revealed that osteopontin expression reached its highest value at day 12 in the -/- group, whilst it reached its equal highest value at day 6 in the $-/+$ group.

When cells were trypsinised at the end of the pre-condition phase and seeded in new wells for the differentiation phase, at day 12, gross visual inspection (Fig. 11a) revealed that the number of cells in the $+/-$ and $+/+$ groups was significantly $(p<0.001)$ smaller as compared to the $-/-$ and $-/+$ groups. The $-/-$ and $-/+$ groups exhibited significantly $(p<0.001)$ higher DNA content than the +/- and +/+ groups, whilst no statistically significant difference was observed between the $-/-$ and $-/+$ and the $+/-$ and $+/+$ groups (Fig. 11b). The highest $(p<0.001)$ calcium content was detected for the $+/+$ group (Fig. 11c).

Cell viability (Fig. 12a), metabolic activity (Fig. $12 b$ ) and DNA content (Fig. 12c) were not affected for the $-/-$ and $-/+$ groups. Although cell viability was not affected, a reduction in cell metabolic activity (Fig. 12b) and DNA content (Fig. 12c) was observed for the $+/-$ and $+/+$ groups as a function of time in culture due to cell detachment.

\section{Discussion}

Whether a stem cell remains multipotent or differentiates into a specific lineage is a result of different signals, whose understanding can potentially improve cell-based tissue engineering therapies. Purified ECM proteins (Ng et al., 2016; Santiago et al., 2009) and decellularised matrices derived from tissues (Agmon and Christman, 2016; Bourgine et al., 2013; Swinehart and Badylak, 2016) and cells (Fitzpatrick and McDevitt, 2015) [e.g. permanently differentiated cells (Bourget et al., 2012; Bourget et al., 2017; Kaukonen et al., 2017; Scherzer et al., 2015), mesenchymal stem cells (Antebi et al., 2015; Cai et al., 2015; Shakouri-Motlagh et al., 2017; Thakkar et al., 2013; Zeitouni et al., 2012), immortalised cells (Kusuma et al., 2017) and cell lines (Hoshiba and Gong, 2018)], alone or in combination with a three- dimensional scaffold, are potent regulators of cell fate. Considering that, in traditional culture systems, ECM deposition is very slow and MMC significantly increases and accelerates ECM deposition, the present study ventured to assess the influence of MMC in human BMSCs that were cultured in the presence or absence of MMC and, subsequently, differentiated towards chondrogenic, adipogenic and osteogenic lineage, again, in the presence or absence of MMC. Carrageenan (a sulphated polysaccharide) was used as a crowding agent since, due to its inherent polydispersity and negative charge, it most effectively excludes volume, resulting in more ECM deposition (Gaspar et al., 2019; Satyam et al., 2014).

In accordance with previous studies (Benny et al., 2015; Chen et al., 2009; Cigognini et al., 2016; Kumar et al., 2015a; Kumar et al., 2015b; Lareu et al., 2007a; Lareu et al., 2007b; Magno et al., 2017; Peng et al., 2012; Prewitz et al., 2015; Rashid et al., 2014; Satyam et al., 2014; Zeiger et al., 2012), MMC prior to differentiation resulted in a significant increase in ECM deposition, without affecting cell metabolic activity (between $70 \%$ and $80 \%$ at days 4 and 7 ) and morphology. TGF- $\beta 1$ and VEGF are secreted by BMSCs (Burlacu et al., 2013; Kwon et al., 2014; Xie et al., 2017) and are involved in chondrogenic and osteogenic differentiation, respectively. Although ECM binds and presents growth factors in a non-canonical way (Droguett et al., 2006; van der Kraan et al., 2002; Wilgus, 2012) and ECM sheets produced under MMC, compared to standard culture conditions, retain larger amount of VEGF, fibroblast growth factor 2 (FGF-2) and hepatocyte growth factor (HGF) (Prewitz et al., 2015), a significant increase in growth factor retention was not observed, possibly attributed to the short time point $(2 \mathrm{~d})$.

During adipogenic induction, although MMC increased collagen type I and IV, adipogenesis was not increased, as judged by oil red $\mathrm{O}$ staining and complementary quantification uptake and FABP4 immunofluorescent staining and complementary fluorescence intensity analysis. Previous studies have demonstrated increased adipogenesis when Ficoll $^{\mathrm{TM}}$ (a neutral non-sulphated crowder) is used as MMC agent (Ang et al., 2014; Lee et al., 2016; Patrikoski et al., 2017). To explain this profound difference in adipogenesis between neutral and negatively charged crowders, one should consider that sulphated polysaccharides, such as fucoidan (Kim et al., 2010), inhibit adipogenesis through the mitogen-activated protein kinase pathway. Further, carrageenan inhibits insulin signalling (Bhattacharyya et al., 2015; Bhattacharyya et al., 2012), which is a potent adipogenic hormone (Klemm et al., 2001). Also, carrageenan may have interacted with FGF-2, which stimulates adipogenic differentiation of mesenchymal stem cells (Kakudo et al., 2007; Kim et al., 2015; Song et al., 2014); after all, a chitosan/ fucoidan hydrogel has been shown to enhance the half-life of FGF-2 (Nakamura et al., 2008) and numerous studies have reported the interaction of 


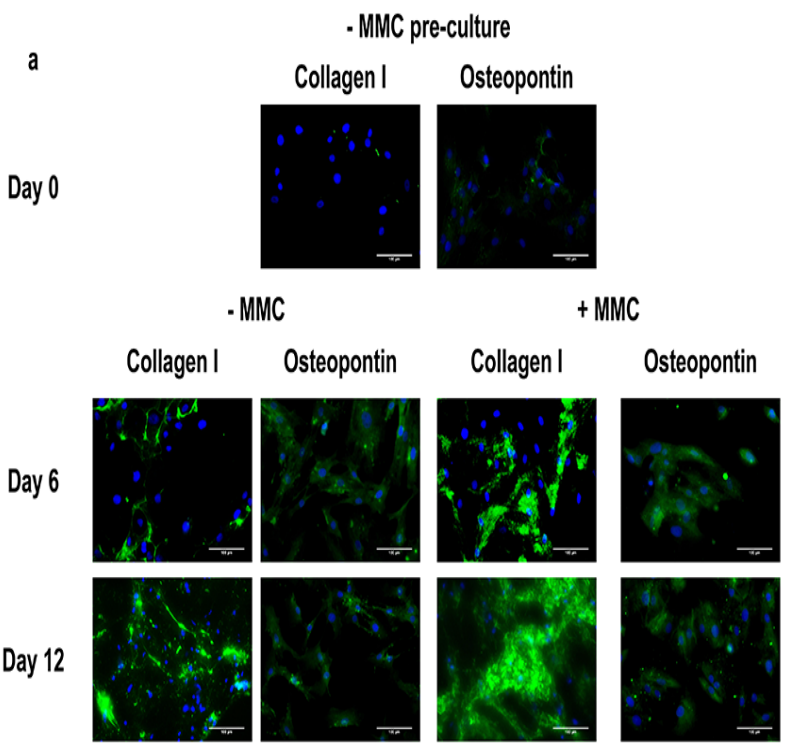

+ MMC pre-culture

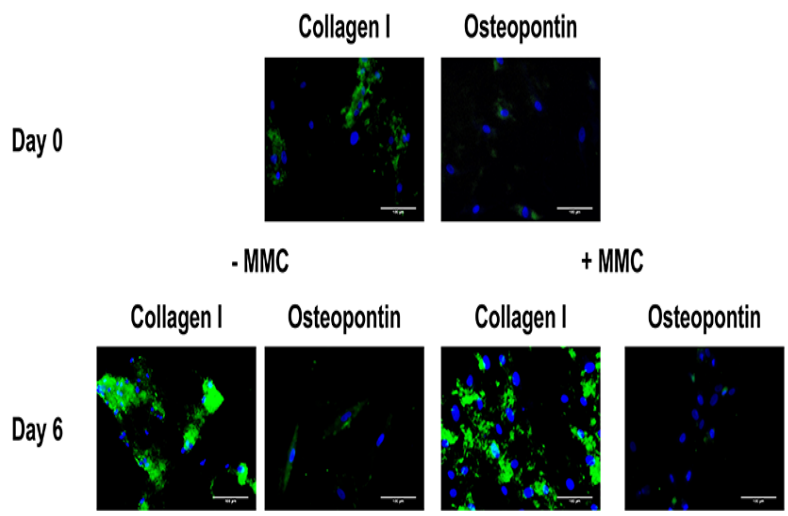

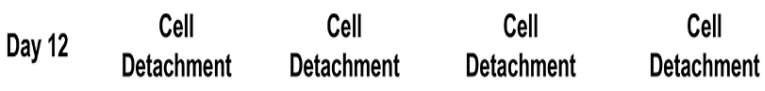

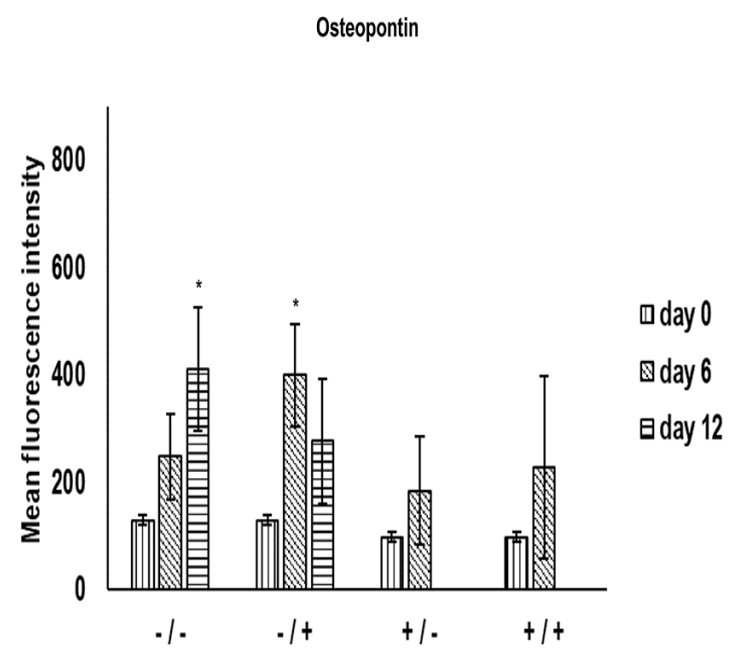

Fig. 10. Collagen type I and osteopontin immunocytochemistry analysis during osteogenic induction. (a) Immunocytochemistry and (b) complementary image intensity analysis revealed that osteopontin expression reached its highest value at day 12 in the -/-MMC-crowded group, whilst it reached its equal highest value at day 6 in the -/+ MMC-crowded group. * indicates statically significant difference. Scale bars: $100 \mu \mathrm{m}$. 
heparin/heparan sulphate with FGF (Kreuger et al., 1999; Kreuger et al., 2001; Turnbull and Gallagher, 1993). Therefore, the chemistry of the crowding agent is important, as previously shown (Kumar et al., 2015b).

When cells were trypsinised at the end of the pre-condition phase and before the differentiation phase, adipogenic differentiation declined in all MMC groups. This is in agreement with previous studies, showing ECM components to reduce/ inhibit adipogenic differentiation. For example, fibronectin interaction with preadipocyte factor 1 (Pref-1) reduces adipogenic differentiation of 3T3L1 cells (Wang et al., 2010). Fish collagen peptides inhibit adipogenic differentiation of 3T3-L cells (Lee et al., 2017). A GAG mixture has been shown to inhibit adipogenic differentiation and enhance chondrocyte features (see below discussion in chondrogenic induction) of mouse embryo fibroblasts (Petrov et al., 2015). Collagen type II-coated plates reduce adipogenic differentiation of BMSCs (Chiu et al., 2012). Collagen-type-I-coated dishes reduce insulin-mediated phosphorylation of Akt in aortic carboxypeptidase-like-protein-overexpressing 3T3L1 cells, resulting in reduced adipogenesis (Gusinjac et al., 2011). Collagen-type-I-coated plates lead to reduced adipogenic differentiation as compared to collagen-type-IV-coated plates in BMSC cultures (John et al., 2002). Last, but certainly not least, when BMSCs are seeded on native decellularised ECM sheets - derived under MMC conditions - and adipogenically differentiated, they exhibit lower lipid droplet accumulation as compared to cells on tissue culture plastic and cells seeded on adipogenically induced ECM derived under MMC conditions (Ang et al., 2014). Therefore, this two-step approach is recommended for enhanced adipogenesis.

During chondrogenic induction, MMC significantly increased collagen type I, II, X and sulphated GAG deposition, whilst no difference in Sox-9 expression was detected. Similarly, previous studies have shown medium supplementation with sulphated polysaccharides to induce chondrogenic differentiation of stem cells (Kawamura et al., 2014) and to suppress mineralisation of a chondrogenic cell line, through direct inhibition of alkaline phosphatase, therefore maintaining their phenotype (Kudo et al., 2017). Enhanced collagen type I and $X$ and decreased collagen type II synthesis are indicative of chondrocyte trans-differentiation and hypertrophy (Descalzi Cancedda et al., 1992; Gu et al., 2014; Kielty et al., 1985; Tekari et al., 2014; von der Mark et al., 1977; von der Mark et al., 1992; Zheng et al., 2003). However, a far more moderate increase in collagen type II (over 100-fold), than in collagen type I (over 30-fold) and collagen type $X$ (over 8-fold), was observed between day 14 and day 0 in MMC cultures, which may indicate progressive differentiation towards the chondrogenic lineage. Further, by day 14, the cells adopted a rounded morphology with a ring around the nucleus, which is a sign of chondrogenesis (Moghadam et al., 2014).

a
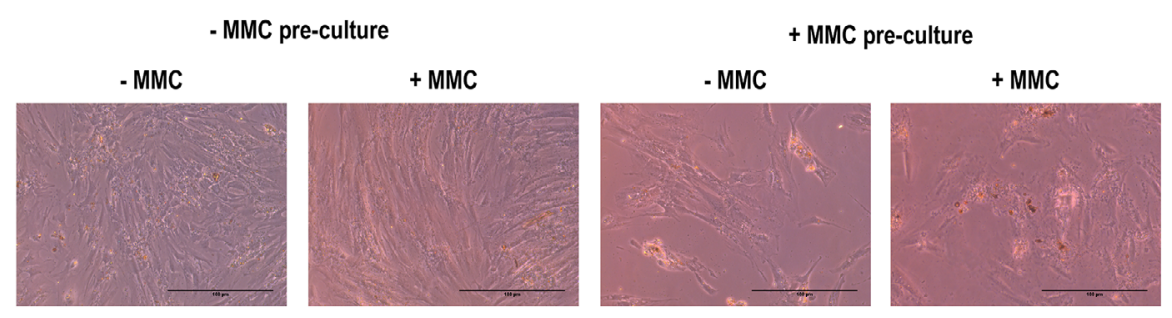

b

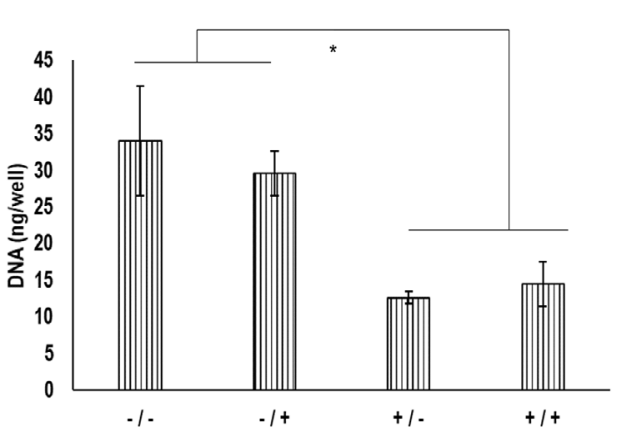

c

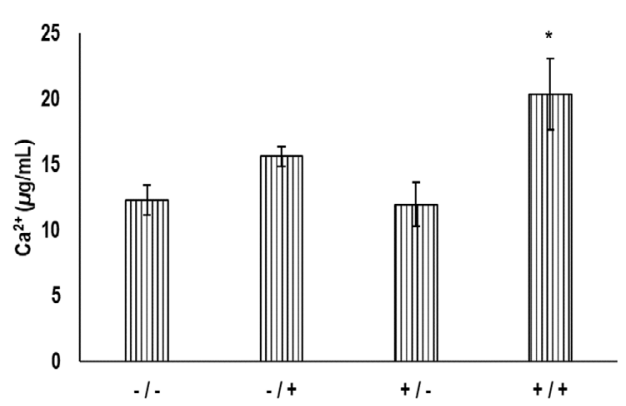

Fig. 11. Visual assessment, DNA content and calcium content during osteogenic induction. When BMSCs were trypsinised at the end of the pre-condition phase and seeded in new wells for the osteogenic differentiation phase, at day 12, (a) gross visual inspection and (b) DNA quantification revealed that the number of cells that were grown in the presence of MMC in the pre-condition phase (+/- and $+/+)$ was significantly lower then the number of cells that were grown in the absence of MMC in the pre-condition phase $(-/-$ and $-/+)$. (c) The highest calcium content was detected with cells that were grown in the presence of MMC in both pre-condition and differentiation phases $(+/+) .{ }^{*}$ indicates statically significant difference. Scale bars: $100 \mu \mathrm{m}$. 
Day 0
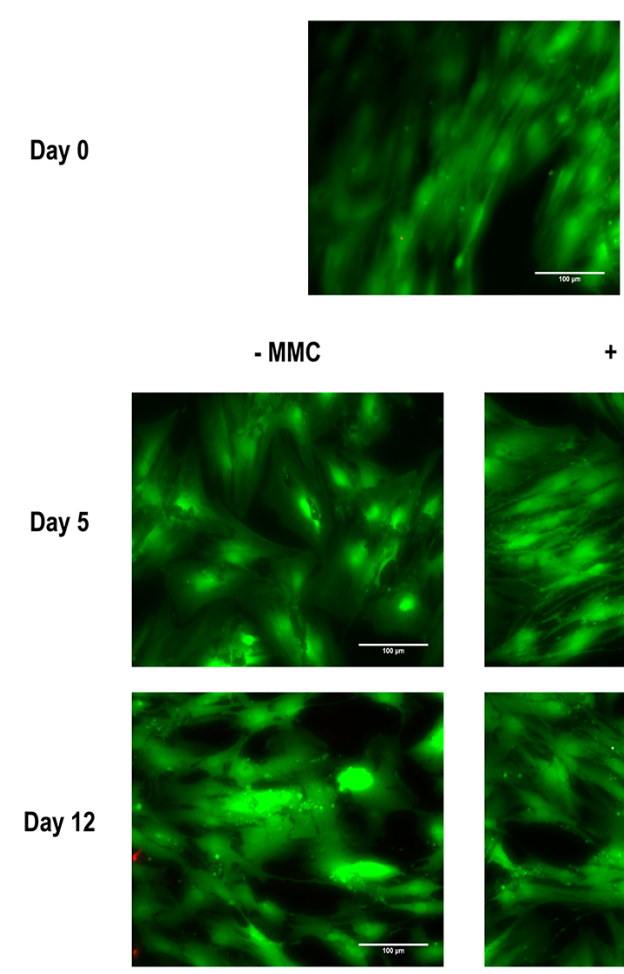

+ MMC
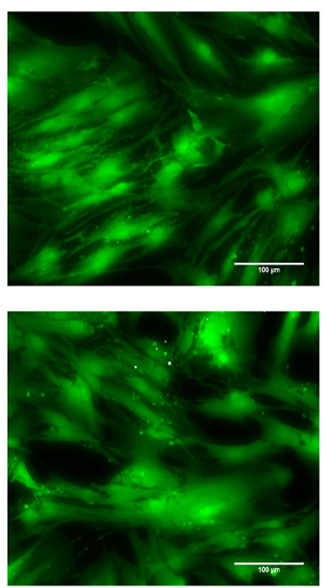

+ MMC pre-culture

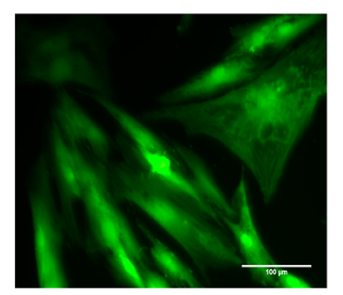

- MMC

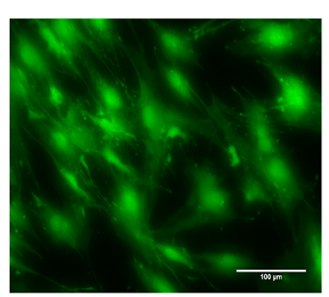

Cell Detachment

Cell Detachment

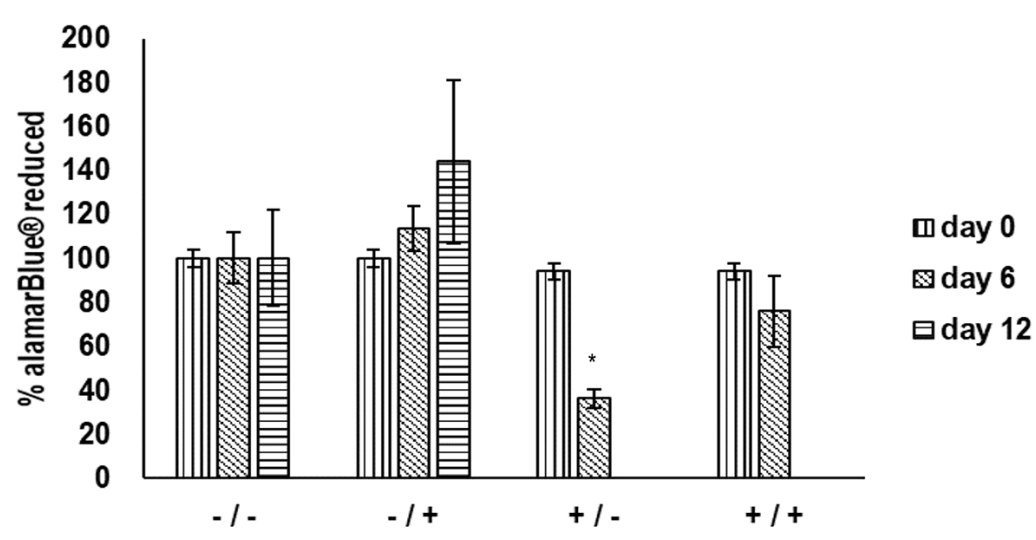

C

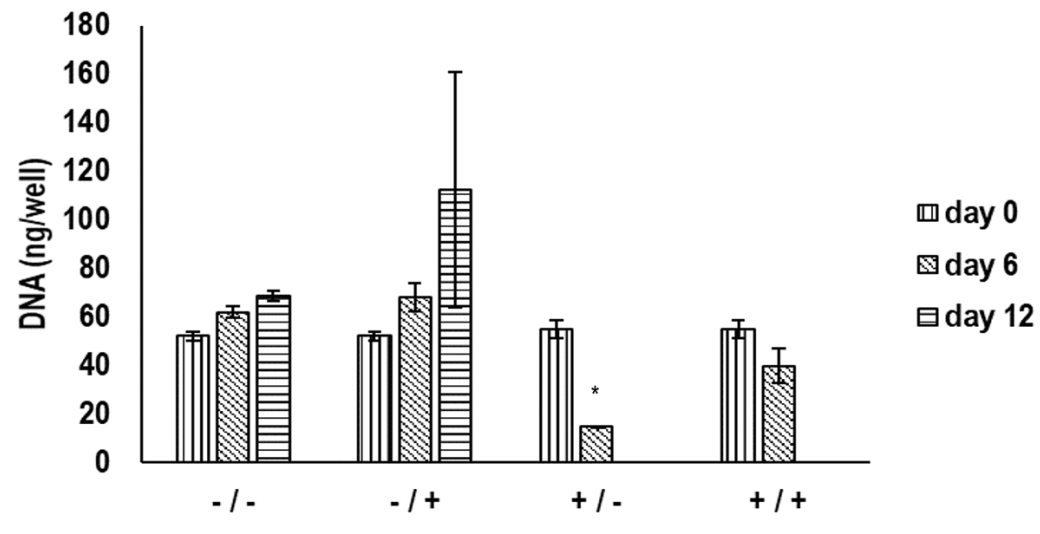

Fig. 12. Cell viability, metabolic activity and DNA content during osteogenic induction. (a) Cell viability, (b) metabolic activity and (c) DNA content were not affected for cells that were pre-conditioned in the absence of MMC (-/- and -/+). Cell detachment prohibited accurate analysis of cell grown in the presence of MMC during the pre-condition phase $(+/-$ and $+/+) .{ }^{*}$ indicates statically significant difference. Scale bars: $100 \mu \mathrm{m}$. 
Also, in the present study, the longest time point was day 14, whilst previous studies have shown formation of cartilage-like tissue from BMSCs (with or without a scaffold) after 4 weeks in culture (Meinel et al., 2004; Xue et al., 2012). Sox-9 expression is also of particular importance, as it has been shown to inhibit bone morphogenetic protein 2 (BMP-2)-induced expression of osteopontin, to enhance collagen type II expression in mesenchymal stem cells (Zhao et al., 2017) and chondrocytes (Bell et al., 1997; Lefebvre et al., 1997; Zhao et al., 1997) and to play a pivotal role in chondrogenesis and chondrocyte differentiation (Akiyama et al., 2002; Bi et al., 1999; Ikegami et al., 2011). Further, forced ectopic Sox-9 expression in vitro (in mouse hypertrophic chondrocytes) and in vivo (in mice) results in downregulation of collagen type $X$ (Leung et al., 2011), which, although its deposition was enhanced in the presence of MMC, was detected in smaller amounts than collagen type I and II. Also, when dextran sulphate is used in porcine bonemarrow stromal cell cultures, aggregates form which are positive for collagen type II at the centre, whereas collagen type I is present only at the periphery (Noble et al., 1995). Collectively, it is the authors' opinion that chondrogenic induction may have been enhanced, but longer time points are required to show the safety of this procedure.

During osteogenic induction, MMC increased mineralisation, collagen type I deposition and osteopontin [an early marker of osteogenic differentiation (Graneli et al., 2014; Zohar et al., 1998)] expression in cells that were grown in the absence of MMC during the pre-condition phase and in the presence of MMC during the differentiation phase. Similarly to the present study, fucoidan, a sulphated polysaccharide, has been shown to enhance osteogenic differentiation of human adiposederived stem cells and human amniotic fluid stem cells (Park et al., 2012). Further, heparan sulphate and dextran sulphate enhance BMP-2 activity, while the desulphated heparin derivatives do not, resulting in osteoblast differentiation and bone formation (Bramono et al., 2012; Takada et al., 2003). In addition, the osteogenic activity of Wnt3a is stimulated to a larger extent with $\mathrm{N}$-sulphation and to a lesser extent with O-sulphation of heparin via a phosphoinositide 3-kinase/Akt/Runt-related transcription factor 2 (RUNX2) pathway (Ling et al., 2010). MMC in precondition and differentiation phases led to cell detachment, which was more profound at day 12 . It is the authors' opinion that cells in the presence of crowding migrated and resided in the de novo synthesised and deposited ECM, rather than on the tissue culture plate, which resulted in cell/ECM detachment.

\section{Conclusions}

The ECMis a dynamic and complex microenvironment, able to influence mesenchymal stem cell differentiation and renewal. While traditional culture systems are not able to mimic ECM-cell interaction, MMC is an in vitro culture technique, based on the biophysical phenomenon of the excluded volume effect, that dramatically enhances and accelerates ECM deposition. The present study assessed the influence of MMC in pre-condition and trilineage differentiation phases of human bone marrow mesenchymal stem cells. Data showed that carrageenan, a sulphated polysaccharide, enhanced chondrogenesis. On the other hand, carrageenan, either due to its sulphated nature or due to enhanced ECM deposition, hindered adipogenesis. Osteogenic differentiation was enhanced when carrageenan was not used in pre-condition medium but, due to cell detachment, it was inconclusive whether carrageenan increased osteogenesis, when it was used in pre-condition medium. Collectively, it is the authors' opinion that carrageenan should be used in BMSC culture when chondrogenic induction is required. With respect to adipogenic (larger extent) and osteogenic (lesser extent) differentiation, it is evidenced that the chemistry of the crowder is important and should be considered in the rational design of cell culture systems.

\section{Acknowledgments}

The authors would like to thank the Science Foundation Ireland/European Regional Development Fund (Grant Agreement Number: 13/RC/2073) and the Science Foundation Ireland, Career Development Award (Grant Agreement Number: 15/CDA/3629) for their financial support. VG and DIZ designed the study and wrote the manuscript. VG conducted the experimental work. VG and DIZ have approved the manuscript.

The authors have no competing interest to declare.

\section{References}

Agmon G, Christman K (2016) Controlling stem cell behavior with decellularized extracellular matrix scaffolds. Curr Opin Solid State Mater Sci 20: 193-201.

Ahmed M, Ffrench-Constant C (2016) Extracellular matrix regulation of stem cell behavior. Curr Stem Cell Rep 2: 197-206.

Akiyama H, Chaboissier M, Martin J, Schedl A, de Crombrugghe B (2002) The transcription factor Sox 9 has essential roles in successive steps of the chondrocyte differentiation pathway and is required for expression of Sox5 and Sox6. Genes Dev 16: 28132828.

Ang XM, Lee MH, Blocki A, Chen C, Ong LL, Asada HH, Sheppard A, Raghunath M (2014) Macromolecular crowding amplifies adipogenesis of human bone marrow-derived mesenchymal stem cells by enhancing the pro-adipogenic microenvironment. Tissue Eng Part A 20: 966-981. 
Antebi B, Zhang Z, Wang Y, Lu Z, Chen XD, Ling J (2015) Stromal-cell-derived extracellular matrix promotes the proliferation and retains the osteogenic differentiation capacity of mesenchymal stem cells on three-dimensional scaffolds. Tissue Eng Part C 21: $171-181$

Aubin K, Safoine M, Proulx M, Audet-Casgrain MA, Cote JF, Tetu FA, Roy A, Fradette J (2015) Characterization of in vitro engineered human adipose tissues: relevant adipokine secretion and impact of TNF-alpha. PLoS One 10: e0137612. DOI: 10.1371/journal.pone.0137612.

Bell D, Leung K, Wheatley S, Ng L, Zhou S, Ling K, Sham M, Koopman P, Tam P, Cheah K (1997) SOX9 directly regulates the type-II collagen gene. Nat Genet 16: 174-178.

Benny P, Badowski C, Lane E, Raghunath M (2015) Making more matrix: enhancing the deposition of dermal-epidermal junction components in vitro and accelerating organotypic skin culture development, using macromolecular crowding. Tissue Eng Part A 21: 183-192.

Bhattacharyya S, Feferman L, Tobacman JK (2015) Carrageenan inhibits insulin signaling through GRB10-mediated decrease in Tyr(P)-IRS1 and through inflammation-induced increase in Ser $(\mathrm{P}) 307$ IRS1. J Biol Chem 290: 10764-10774.

Bhattacharyya S, O'Sullivan I, Katyal S, Unterman T, Tobacman J (2012) Exposure to the common food additive carrageenan leads to glucose intolerance, insulin resistance and inhibition of insulin signalling in HepG2 cells and C57BL/6J mice. Diabetologia 55: 194-203.

Bi W, Deng J, Zhang Z, Behringer $R$, de Crombrugghe B (1999) Sox9 is required for cartilage formation. Nat Genet 22: 85-89.

Bourget J, Gauvin R, Larouche D, Lavoie A, Labbé R, Auger F, Germain L (2012) Human fibroblastderived ECM as a scaffold for vascular tissue engineering. Biomaterials 33: 9205-9213.

Bourget J, Laterreur V, Gauvin R, Guillemette M, Miville-Godin C, Mounier M, Tondreau M, Tremblay C, Labbé R, Ruel J, Auger F, Veres T, Germain L (2017) Microstructured human fibroblast-derived extracellular matrix scaffold for vascular media fabrication. J Tissue Eng Regen Med 11: 2479-2489.

Bourgine P, Pippenger B, Todorov AJ, Tchang L, Martin I (2013) Tissue decellularization by activation of programmed cell death. Biomaterials 34: 6099-6108.

Bramono D, Murali S, Rai B, Ling L, Poh W, Lim Z, Stein G, Nurcombe V, van Wijnen A, Cool S (2012) Bone marrow-derived heparan sulfate potentiates the osteogenic activity of bone morphogenetic protein-2 (BMP-2). Bone 50: 954-964.

Burlacu A, Grigorescu G, Rosca AM, Preda MB, Simionescu M (2013) Factors secreted by mesenchymal stem cells and endothelial progenitor cells have complementary effects on angiogenesis in vitro. Stem Cells Dev 22: 643-653.

Cai R, Nakamoto T, Kawazoe N, Chen G (2015) Influence of stepwise chondrogenesis-mimicking 3D extracellular matrix on chondrogenic differentiation of mesenchymal stem cells. Biomaterials 52: 199-207.

Cantin-Warren L, Guignard R, Cortez Ghio S, Larouche D, Auger F, Germain L (2018) Specialized living wound dressing based on the self-assembly approach of tissue engineering. J Funct Biomater 9: E53. DOI: 10.3390/jfb9030053.

Capella-Monsonís H, Coentro J, Graceffa V, Wu Z, Zeugolis D (2018) An experimental toolbox for characterization of mammalian collagen type I in biological specimens. Nat Protoc 13: 507-529.

Chen C, Loe F, Blocki A, Peng Y, Raghunath M (2011) Applying macromolecular crowding to enhance extracellular matrix deposition and its remodeling in vitro for tissue engineering and cellbased therapies. Adv Drug Deliv Rev 63: 277-290.

Chen C, Peng Y, Wang Z, Fish P, Kaar J, Koepsel R, Russell A, Lareu R, Raghunath M (2009) The Scarin-a-Jar: Studying potential antifibrotic compounds from the epigenetic to extracellular level in a single well. Br J Pharmacol 158: 1196-1209.

Cheng C, Solorio L, Alsberg E (2014) Decellularized tissue and cell-derived extracellular matrices as scaffolds for orthopaedic tissue engineering. Biotechnol Adv 32: 462-484.

Chiu L, Yeh T, Huang H, Leu S, Yang C, Tsai Y (2012) Diverse effects of type II collagen on osteogenic and adipogenic differentiation of mesenchymal stem cells. J Cell Physiol 227: 2412-2420.

Choi JS, Kim BS, Kim JD, Choi YC, Lee HY, Cho YW (2012) In vitro cartilage tissue engineering using adipose-derived extracellular matrix scaffolds seeded with adipose-derived stem cells. Tissue Eng Part A 18: 80-92.

Cigognini D, Gaspar D, Kumar P, Satyam A, Alagesan S, Sanz-Nogues C, Griffin M, O'Brien T, Pandit A, Zeugolis DI (2016) Macromolecular crowding meets oxygen tension in human mesenchymal stem cell culture - a step closer to physiologically relevant in vitro organogenesis. Sci Rep 6: 30746. DOI: 10.1038/srep30746.

Cigognini D, Lomas A, Kumar P, Satyam A, English A, Azeem A, Pandit A, Zeugolis D (2013) Engineering in vitro microenvironments for cell based therapies and drug discovery. Drug Discov Today 18: 1099-1108.

Crane JL, Cao X (2014) Bone marrow mesenchymal stem cells and TGF-beta signaling in bone remodeling. J Clin Invest 124: 466-472.

D'Andrea F, De Francesco F, Ferraro GA, Desiderio V, Tirino V, De Rosa A, Papaccio G (2008) Large-scale production of human adipose tissue from stem cells: a new tool for regenerative medicine and tissue banking. Tissue Eng Part C 14: 233-242.

Descalzi Cancedda F, Gentili C, Manduca P, Cancedda R (1992) Hypertrophic chondrocytes undergo further differentiation in culture. J Cell Biol 117: 427-435.

Droguett R, Cabello-Verrugio C, Riquelme C, Brandan E (2006) Extracellular proteoglycans modify TGF-beta bio-availability attenuating its signaling 
during skeletal muscle differentiation. Matrix Biol 25: 332-341.

Fitzpatrick L, McDevitt T (2015) Cell-derived matrices for tissue engineering and regenerative medicine applications. Biomater Sci 3: 12-24.

Gaspar D, Fuller K, Zeugolis D (2019) Polydispersity and negative charge are key modulators of extracellular matrix deposition under macromolecular crowding conditions. Acta Biomater 88: 197-210.

Gaspar D, Ryan C, Zeugolis D (2019) Multifactorial bottom-up bioengineering approaches for the development of living tissue substitutes. FASEB J 33. DOI: 10.1096/fj.201802451R.

Gattazzo F, Urciuolo A, Bonaldo P (2014) Extracellular matrix: a dynamic microenvironment for stem cell niche. Biochim Biophys Acta 1840: 25062519.

Ge Y, Gong YY, Xu Z, Lu Y, Fu W (2016) The application of sheet technology in cartilage tissue engineering. Tissue Eng Part B 22: 114-124.

Geng W, Ma D, Yan X, Liu L, Cui J, Xie X, Li $H$, Chen F (2013) Engineering tubular bone using mesenchymal stem cell sheets and coral particles. Biochem Biophys Res Commun 433: 595-601.

George P, Bliss T, Hua T, Lee A, Oh B, Levinson A, Mehta S, Sun G, Steinberg G (2017) Electrical preconditioning of stem cells with a conductive polymer scaffold enhances stroke recovery. Biomaterials 142: 31-40.

Goldberg A, Mitchell K, Soans J, Kim L, Zaidi R (2017) The use of mesenchymal stem cells for cartilage repair and regeneration: a systematic review. J Orthop Surg Res 12: 39. DOI: 10.1186/s13018-0170534-y.

Graceffa V, Vinatier C, Guicheux J, Evans C, Stoddart M, Alini M, Zeugolis D (2018) State of art and limitations in genetic engineering to induce stable chondrogenic phenotype. Biotechnol Adv 36: 18551869.

Graneli C, Thorfve A, Ruetschi U, Brisby H, Thomsen P, Lindahl A, Karlsson C (2014) Novel markers of osteogenic and adipogenic differentiation of human bone marrow stromal cells identified using a quantitative proteomics approach. Stem Cell Res 12: 153-165.

Gu J, Lu Y, Li F, Qiao L, Wang Q, Li N, Borgia J, Deng Y, Lei G, Zheng Q (2014) Identification and characterization of the novel Col10a1 regulatory mechanism during chondrocyte hypertrophic differentiation. Cell Death Dis 5: e1469. DOI: 10.1038/ cddis.2014.444.

Guilak F, Cohen DM, Estes BT, Gimble JM, Liedtke W, Chen CS (2009) Control of stem cell fate by physical interactions with the extracellular matrix. Cell Stem Cell 5: 17-26.

Gusinjac A, Gagnon A, Sorisky A (2011) Effect of collagen I and aortic carboxypeptidase-like protein on 3T3-L1 adipocyte differentiation. Metabolism 60: 782-788.
Harris G, Raitman I, Schwarzbauer J (2018) Cell-derived decellularized extracellular matrices. Methods Cell Biol 143: 97-114.

Hawinkels LJ, Verspaget HW, van Duijn W, van der Zon JM, Zuidwijk K, Kubben FJ, Verheijen JH, Hommes DW, Lamers CB, Sier CF (2007) Tissue level, activation and cellular localisation of TGF-beta1 and association with survival in gastric cancer patients. Br J Cancer 97: 398-404.

He A, Liu L, Luo X, Liu Y, Liu Y, Liu F, Wang X, Zhang Z, Zhang W, Liu W, Cao Y, Zhou G (2017) Repair of osteochondral defects with in vitro engineered cartilage based on autologous bone marrow stromal cells in a swine model. Sci Rep 7: 40489. DOI: $10.1038 /$ srep40489.

Heng BC, Cao T, Stanton LW, Robson P, Olsen B (2004) Strategies for directing the differentiation of stem cells into the osteogenic lineage in vitro. J Bone Miner Res 19: 1379-1394.

Herberts CA, Kwa MS, Hermsen HP (2011) Risk factors in the development of stem cell therapy. J Transl Med 9: 29. DOI: 10.1186/1479-5876-9-29.

Hoshiba T, Gong J (2018) Fabrication of cellderived decellularized matrices on three-dimensional (3D)-printed biodegradable polymer scaffolds. Microsyst Technol 24: 613-617.

Hoshiba T, Kawazoe N, Tateishi T, Chen G (2009) Development of stepwise osteogenesis-mimicking matrices for the regulation of mesenchymal stem cell functions. J Biol Chem 284: 31164-31173.

Hoshiba T, Kawazoe N, Tateishi T, Chen G (2010) Development of extracellular matrices mimicking stepwise adipogenesis of mesenchymal stem cells. Adv Mater 22: 3042-3047.

Huang Z, Godkin O, Schulze-Tanzil G (2017) The challenge in using mesenchymal stromal cells for recellularization of decellularized cartilage. Stem Cell Rev 13: 50-67.

Ikegami D, Akiyama H, Suzuki A, Nakamura T, Nakano T, Yoshikawa H, Tsumaki N (2011) Sox9 sustains chondrocyte survival and hypertrophy in part through Pik3ca-Akt pathways. Development 138: 1507-1519.

Itokazu M, Wakitani S, Mera H, Tamamura Y, Sato Y, Takagi M, Nakamura H (2016) Transplantation of scaffold-free cartilage-like cell-sheets made from human bone marrow mesenchymal stem cells for cartilage repair: a preclinical study. Cartilage 7: 361372.

John A, Ikada Y, Tabata Y (2002) Tissue engineered bone and adipose tissue-as in vitro study. Trends Biomater Artif Organs 16: 28-33.

Kakudo N, Shimotsuma A, Kusumoto K (2007) Fibroblast growth factor-2 stimulates adipogenic differentiation of human adipose-derived stem cells. Biochem Biophys Res Commun 359: 239-244.

Kaukonen R, Jacquemet G, Hamidi H, Ivaska J (2017) Cell-derived matrices for studying cell proliferation and directional migration in a complex 3D microenvironment. Nat Protoc 12: 2376-2390. 
Kawamura D, Funakoshi T, Mizumoto S, Sugahara K, Iwasaki N (2014) Sulfation patterns of exogenous chondroitin sulfate affect chondrogenic differentiation of ATDC5 cells. J Orthop Sci 19: 10281035.

Kielty C, Kwan A, Holmes D, Schor S, Grant M (1985) Type X collagen, a product of hypertrophic chondrocytes. Biochem J 227: 545-554.

Kim K, Lee O, Lee B (2010) Fucoidan, a sulfated polysaccharide, inhibits adipogenesis through the mitogen-activated protein kinase pathway in 3T3-L1 preadipocytes. Life Sci 86: 791-797.

Kim S, Ahn C, Bong N, Choe S, Lee D (2015) Biphasic effects of FGF2 on adipogenesis. PLoS One 10: e0120073. DOI: 10.1371/journal.pone.0120073.

Kim SH, Turnbull J, Guimond S (2011) Extracellular matrix and cell signalling: the dynamic cooperation of integrin, proteoglycan and growth factor receptor. J Endocrinol 209: 139-151.

Klemm D, Leitner J, Watson P, Nesterova A, Reusch J, Goalstone M, Draznin B (2001) Insulininduced adipocyte differentiation. Activation of CREB rescues adipogenesis from the arrest caused by inhibition of prenylation. J Biol Chem 276: 28430 28435.

Kreuger J, Prydz K, Pettersson R, Lindahl U, Salmivirta M (1999) Characterization of fibroblast growth factor 1 binding heparan sulfate domain. Glycobiology 9: 723-729.

Kreuger J, Salmivirta M, Sturiale L, GiménezGallego G, Lindahl U (2001) Sequence analysis of heparan sulfate epitopes with graded affinities for fibroblast growth factors 1 and 2. J Biol Chem 276: 30744-30752.

Kudo T, Nakatani S, Kakizaki M, Arai A, Ishida K, Wada M, Kobata K (2017) Supplemented chondroitin sulfate and hyaluronic acid suppress mineralization of the chondrogenic cell line, ATDC5, via direct inhibition of alkaline phosphatase. Biol Pharm Bull 40: 2075-2080.

Kumar P, Satyam A, Fan X, Collin E, Rochev Y, Rodriguez B, Gorelov A, Dillon S, Joshi L, Raghunath M, Pandit A, Zeugolis D (2015a) Macromolecularly crowded in vitro microenvironments accelerate the production of extracellular matrix-rich supramolecular assemblies. Sci Rep 5: 8729. DOI: 10.1038/srep08729.

Kumar P, Satyam A, Fan X, Rochev Y, Rodriguez B, Gorelov A, Joshi L, Raghunath M, Pandit A, Zeugolis D (2015b) Accelerated development of supramolecular corneal stromal-like assemblies from corneal fibroblasts in the presence of macromolecular crowders. Tissue Eng Part C 21: 660-670.

Kusuma GD, Brennecke SP, O'Connor AJ, Kalionis B, Heath DE (2017) Decellularized extracellular matrices produced from immortal cell lines derived from different parts of the placenta support primary mesenchymal stem cell expansion. PLoS One 12: e0171488. DOI: 10.1371/journal.pone.0171488.

Kwon HM, Hur SM, Park KY, Kim CK, Kim YM, Kim HS, Shin HC, Won MH, Ha KS, Kwon YG,
Lee DH, Kim YM (2014) Multiple paracrine factors secreted by mesenchymal stem cells contribute to angiogenesis. Vascul Pharmacol 63: 19-28.

Kwon SH, Lee TJ, Park J, Hwang JE, Jin M, Jang HK, Hwang NS, Kim BS (2013) Modulation of BMP-2-induced chondrogenic versus osteogenic differentiation of human mesenchymal stem cells by cell-specific extracellular matrices. Tissue Eng Part A 19: 49-58.

L'Heureux N, Dusserre N, Konig G, Victor B, Keire P, Wight T, Chronos N, Kyles A, Gregory C, Hoyt G, Robbins R, McAllister T (2006) Human tissue-engineered blood vessels for adult arterial revascularization. Nat Med 12: 361-365.

Labbe B, Marceau-Fortier G, Fradette J (2011) Cell sheet technology for tissue engineering: the selfassembly approach using adipose-derived stromal cells. Methods Mol Biol 702: 429-441.

Lareu R, Arsianti I, Subramhanya H, Yanxian P, Raghunath M (2007a) In vitro enhancement of collagen matrix formation and crosslinking for applications in tissue engineering: a preliminary study. Tissue Eng 13: 385-391.

Lareu R, Subramhanya K, Peng Y, Benny P, Chen C, Wang Z, Rajagopalan R, Raghunath M (2007b) Collagen matrix deposition is dramatically enhanced in vitro when crowded with charged macromolecules: the biological relevance of the excluded volume effect. FEBS Lett 581: 2709-2714.

Lawrence DA, Pircher R, Kryceve-Martinerie C, Jullien P (1984) Normal embryo fibroblasts release transforming growth factors in a latent form. J Cell Physiol 121: 184-188.

Lee E, Hur J, Ham S, Jo Y, Lee S, Choi M, Seo H (2017) Fish collagen peptide inhibits the adipogenic differentiation of preadipocytes and ameliorates obesity in high fat diet-fed mice. Int J Biol Macromol 104(Pt A): 281-286.

Lee MH, Goralczyk AG, Kriszt R, Ang XM, Badowski C, Li Y, Summers SA, Toh SA, Yassin MS, Shabbir A, Sheppard A, Raghunath M (2016) ECM microenvironment unlocks brown adipogenic potential of adult human bone marrow-derived MSCs. Sci Rep 6: 21173. DOI: 10.1038/srep21173.

Lefebvre V, Huang W, Harley V, Goodfellow P, de Crombrugghe B (1997) SOX9 is a potent activator of the chondrocyte-specific enhancer of the pro alpha1(II) collagen gene. Mol Cell Biol 17: 2336-2346.

Lepperdinger G, Brunauer R, Jamnig A, Laschober G, Kassem M (2008) Controversial issue: is it safe to employ mesenchymal stem cells in cell-based therapies? Exp Gerontol 43: 1018-1023.

Leung V, Gao B, Leung K, Melhado I, Wynn S, Au T, Dung N, Lau J, Mak A, Chan D, Cheah K (2011) SOX9 governs differentiation stage-specific gene expression in growth plate chondrocytes via direct concomitant transactivation and repression. PLoS Genet 7: e1002356. DOI: 10.1371/journal. pgen.1002356.

Li Z, Xu X, Wang W, Kratz K, Sun X, Zou J, Deng Z, Jung F, Gossen M, Ma N, Lendlein A (2017) 
Modulation of the mesenchymal stem cell migration capacity via preconditioning with topographic microstructure. Clin Hemorheol Microcirc 67: 267278.

Licht T, Rothe G, Kreisel T, Wolf B, Benny O, Rooney A, Ffrench-Constant C, Enikolopov G, Keshet E (2016) VEGF preconditioning leads to stem cell remodeling and attenuates age-related decay of adult hippocampal neurogenesis. Proc Natl Acad Sci U S A 113: E7828-E7836.

Lin S, Lee W, Feng Q, Xu L, Wang B, Man G, Chen Y, Jiang X, Bian L, Cui L, Wei B, Li G (2017) Synergistic effects on mesenchymal stem cell-based cartilage regeneration by chondrogenic preconditioning and mechanical stimulation. Stem Cell Res Ther 8: 221. DOI: 10.1186/s13287-017-0672-5.

Ling L, Dombrowski C, Foong K, Haupt L, Stein G, Nurcombe V, van Wijnen A, Cool S (2010) Synergism between Wnt3a and heparin enhances osteogenesis via a phosphoinositide 3-kinase/Akt/ RUNX2 pathway. J Biol Chem 285: 26233-26244.

Lu P, Takai K, Weaver VM, Werb Z (2011) Extracellular matrix degradation and remodeling in development and disease. Cold Spring Harb Perspect Biol 3. pii: a005058. DOI: 10.1101/cshperspect. a005058.

Luo M, Chen Y (2018) Application of stem cellderived retinal pigmented epithelium in retinal degenerative diseases: present and future. Int J Ophthalmol 11: 150-159.

Ma G, Zhao JL, Mao M, Chen J, Dong ZW, Liu YP (2017) Scaffold-based delivery of bone marrow mesenchymal stem cell sheet fragments enhances new bone formation in vivo. J Oral Maxillofac Surg 75: 92-104.

Magno V, Friedrichs J, Weber H, Prewitz M, Tsurkan M, Werner C (2017) Macromolecular crowding for tailoring tissue-derived fibrillated matrices. Acta Biomater 55: 109-119.

Mao Y, Hoffman T, Wu A, Goyal R, Kohn J (2017) Cell type-specific extracellular matrix guided the differentiation of human mesenchymal stem cells in 3D polymeric scaffolds. J Mater Sci Mater Med 28: 100. DOI: 10.1007/s10856-017-5912-9.

Marinkovic M, Block TJ, Rakian R, Li Q, Wang E, Reilly MA, Dean DD, Chen XD (2016) One size does not fit all: developing a cell-specific niche for in vitro study of cell behavior. Matrix Biol 52-54: 426-441.

Meinel L, Hofmann S, Karageorgiou V, Zichner L, Langer R, Kaplan D, Vunjak-Novakovic G (2004) Engineering cartilage-like tissue using human mesenchymal stem cells and silk protein scaffolds. Biotechnol Bioeng 88: 379-391.

Minton A (1997) Influence of excluded volume upon macromolecular structure and associations in 'crowded' media. Curr Opin Biotechnol 8: 65-69.

Minton A (2000) Implications of macromolecular crowding for protein assembly. Curr Opin Struct Biol 10: 34-39.

Minton AP (1993) Macromolecular crowding and molecular recognition. J Mol Recognit 6: 211-214.
Miyagawa S, Domae K, Yoshikawa Y, Fukushima S, Nakamura T, Saito A, Sakata Y, Hamada S, Toda K, Pak K, Takeuchi M, Sawa Y (2017) Phase I clinical trial of autologous stem cell-sheet transplantation therapy for treating cardiomyopathy. J Am Heart Assoc 6: pii: e003918. DOI: 10.1161/JAHA.116.003918.

Moghadam FH, Tayebi T, Dehghan M, Eslami G, Nadri H, Moradi A, Vahedian-Ardakani H, Barzegar K (2014) Differentiation of bone marrow mesenchymal stem cells into chondrocytes after short term culture in alkaline medium. Int J Hematol Oncol Stem Cell Res 8: 12-19.

Nakamura S, Nambu M, Ishizuka T, Hattori H, Kanatani Y, Takase B, Kishimoto S, Amano Y, Aoki H, Kiyosawa T, Ishihara M, Maehara T (2008) Effect of controlled release of fibroblast growth factor-2 from chitosan/fucoidan micro complex-hydrogel on in vitro and in vivo vascularization. J Biomed Mater Res A 85: 619-627.

Ng J, Wei Y, Zhou B, Burapachaisri A, Guo E, Vunjak-Novakovic G (2016) Extracellular matrix components and culture regimen selectively regulate cartilage formation by self-assembling human mesenchymal stem cells in vitro and in vivo. Stem Cell Res Ther 7: 183. DOI: 10.1186/s13287-016-0447-4.

Noble B, Dean V, Loveridge N, Thomson B (1995) Dextran sulfate promotes the rapid aggregation of porcine bone-marrow stromal cells. Bone 17: 375-382.

Pagani FD, DerSimonian H, Zawadzka A, Wetzel K, Edge AS, Jacoby DB, Dinsmore JH, Wright S, Aretz TH, Eisen HJ, Aaronson KD (2003) Autologous skeletal myoblasts transplanted to ischemia-damaged myocardium in humans. Histological analysis of cell survival and differentiation. J Am Coll Cardiol 41: 879-888.

Park SJ, Lee KW, Lim DS, Lee S (2012) The sulfated polysaccharide fucoidan stimulates osteogenic differentiation of human adipose-derived stem cells. Stem Cells Dev 21: 2204-2211.

Patrikoski M, Lee MHC, Makinen L, Ang XM, Mannerstrom B, Raghunath M, Miettinen S (2017) Effects of macromolecular crowding on human adipose stem cell culture in fetal bovine serum, human serum, and defined xeno-free/serum-free conditions. Stem Cells Int 2017: 6909163. DOI: 10.1155/2017/6909163.

Pellegrini G, Traverso CE, Franzi AT, Zingirian M, Cancedda R, De Luca M (1997) Long-term restoration of damaged corneal surfaces with autologous cultivated corneal epithelium. Lancet 349: 990-993.

Peng Y, Bocker M, Holm J, Toh W, Hughes C, Kidwai F, Lajoie G, Cao T, Lyko F, Raghunath M (2012) Human fibroblast matrices bio-assembled under macromolecular crowding support stable propagation of human embryonic stem cells. J Tissue Eng Regen Med 6: e74-e86.

Petrov P, Granados N, Chetrit C, MartínezPuig D, Palou A, Bonet M (2015) Synergistic effects of a mixture of glycosaminoglycans to inhibit adipogenesis and enhance chondrocyte features in multipotent cells. Cell Physiol Biochem 37: 1792-1806. 
Prewitz MC, Stissel A, Friedrichs J, Traber N, Vogler S, Bornhauser M, Werner C (2015) Extracellular matrix deposition of bone marrow stroma enhanced by macromolecular crowding. Biomaterials 73: 60-69.

Qi Y, Du Y, Li W, Dai X, Zhao T, Yan W (2014) Cartilage repair using mesenchymal stem cell (MSC) sheet and MSCs-loaded bilayer PLGA scaffold in a rabbit model. Knee Surg Sports Traumatol Arthrosc 22: 1424-1433.

Rao Pattabhi S, Martinez JS, Keller TC, 3rd (2014) Decellularized ECM effects on human mesenchymal stem cell stemness and differentiation. Differentiation 88: 131-143.

Rashid R, Lim NS, Chee SM, Png SN, Wohland T, Raghunath M (2014) Novel use for polyvinylpyrrolidone as a macromolecular crowder for enhanced extracellular matrix deposition and cell proliferation. Tissue Eng Part C 20: 994-1002.

Santiago JA, Pogemiller R, Ogle BM (2009) Heterogeneous differentiation of human mesenchymal stem cells in response to extended culture in extracellular matrices. Tissue Eng Part A 15: 3911-3922.

Satyam A, Kumar P, Fan X, Gorelov A, Rochev Y, Joshi L, Peinado H, Lyden D, Thomas B, Rodriguez B, Raghunath M, Pandit A, Zeugolis D (2014) Macromolecular crowding meets tissue engineering by self-assembly: a paradigm shift in regenerative medicine. Adv Mater 26: 3024-3034.

Sawa Y, Miyagawa S, Sakaguchi T, Fujita T, Matsuyama A, Saito A, Shimizu T, Okano T (2012) Tissue engineered myoblast sheets improved cardiac function sufficiently to discontinue LVAS in a patient with DCM: report of a case. Surg Today 42: 181-184.

Scherzer M, Waigel S, Donninger H, Arumugam V, Zacharias W, Clark G, Siskind L, Soucy P, Beverly L (2015) Fibroblast-derived extracellular matrices: an alternative cell culture system that increases metastatic cellular properties. PLoS One 10: e0138065. DOI: 10.1371/journal.pone.0138065.

See EY, Toh SL, Goh JC (2010) Multilineage potential of bone-marrow-derived mesenchymal stem cell cell sheets: implications for tissue engineering. Tissue Eng Part A 16: 1421-1431.

Shakouri-Motlagh A, O'Connor A, Brennecke S, Kalionis B, Heath D (2017) Native and solubilized decellularized extracellular matrix: a critical assessment of their potential for improving the expansion of mesenchymal stem cells. Acta Biomater 55: 1-12.

Smith Q, Gerecht S (2018) Extracellular matrix regulation of stem cell fate. Curr Stem Cell Rep 4: 13-21.

Solorio LD, Vieregge EL, Dhami CD, Dang PN, Alsberg E (2012) Engineered cartilage via self-assembled hMSC sheets with incorporated biodegradable gelatin microspheres releasing transforming growth factor-beta1. J Control Release 158: 224-232.

Song X, Li Y, Chen X, Yin G, Huang Q, Chen Y, Xu G, Wang L (2014) bFGF promotes adipocyte differentiation in human mesenchymal stem cells derived from embryonic stem cells. Genet Mol Biol 37: 127-134.

Swinehart I, Badylak S (2016) Extracellular matrix bioscaffolds in tissue remodeling and morphogenesis. Dev Dyn 245: 351-360.

Takada T, Katagiri T, Ifuku M, Morimura N, Kobayashi M, Hasegawa K, Ogamo A, Kamijo R (2003) Sulfated polysaccharides enhance the biological activities of bone morphogenetic proteins. J Biol Chem 278: 43229-43235.

Tang C, Xu Y, Jin C, Min BH, Li Z, Pei X, Wang L (2013) Feasibility of autologous bone marrow mesenchymal stem cell-derived extracellular matrix scaffold for cartilage tissue engineering. Artif Organs 37: E179-190.

Tekari A, Luginbuehl R, Hofstetter W, Egli R (2014) Chondrocytes expressing intracellular collagen type II enter the cell cycle and co-express collagen type I in monolayer culture. J Orthop Res 32: 1503-1511.

Thakkar S, Ghebes CA, Ahmed M, Kelder C, van Blitterswijk CA, Saris D, Fernandes HA, Moroni L (2013) Mesenchymal stromal cell-derived extracellular matrix influences gene expression of chondrocytes. Biofabrication 5: 025003. DOI: 10.1088/1758-5082/5/2/025003.

Thibault RA, Scott Baggett L, Mikos AG, Kasper FK (2010) Osteogenic differentiation of mesenchymal stem cells on pregenerated extracellular matrix scaffolds in the absence of osteogenic cell culture supplements. Tissue Eng Part A 16: 431-440.

Trombi L, Danti S, Savelli S, Moscato S, D'Alessandro D, Ricci C, Giannotti S, Petrini M (2016) Mesenchymal stromal cell culture and delivery in autologous conditions: a smart approach for orthopedic applications. J Vis Exp 8. DOI: 10.3791/54845.

Tsai R, Li L, Chen J (2000) Reconstruction of damaged corneas by transplantation of autologous limbal epithelial cells. N Engl J Med 343: 86-93.

Turnbull J, Gallagher J (1993) Heparan sulphate: functional role as a modulator of fibroblast growth factor activity. Biochem Soc Trans 21: 477-482.

van der Kraan PM, Buma P, van Kuppevelt T, van den Berg WB (2002) Interaction of chondrocytes, extracellular matrix and growth factors: relevance for articular cartilage tissue engineering. Osteoarthritis Cartilage 10: 631-637.

Vermette M, Trottier V, Menard V, Saint-Pierre L, Roy A, Fradette J (2007) Production of a new tissueengineered adipose substitute from human adiposederived stromal cells. Biomaterials 28: 2850-2860.

von der Mark K, Gauss V, von der Mark H, Müller P (1977) Relationship between cell shape and type of collagen synthesised as chondrocytes lose their cartilage phenotype in culture. Nature 267: 531-532.

von der Mark K, Kirsch T, Nerlich A, Kuss A, Weseloh G, Glückert K, Stöss H (1992) Type X collagen synthesis in human osteoarthritic cartilage. Indication of chondrocyte hypertrophy. Arthritis Rheum 35: 806-811. 
Wang X, Li G, Guo J, Yang L, Liu Y, Sun Q, Li R, Yu W (2017) Hybrid composites of mesenchymal stem cell sheets, hydroxyapatite, and platelet-rich fibrin granules for bone regeneration in a rabbit calvarial critical-size defect model. Exp Ther Med 13: 18911899.

Wang Y, Zhao L, Smas C, Sul H (2010) Pref1 interacts with fibronectin to inhibit adipocyte differentiation. Mol Cell Biol 30: 3480-3492.

Watt F, Huck W (2013) Role of the extracellular matrix in regulating stem cell fate. Nat Rev Mol Cell Biol 14: 467-473.

Wilgus TA (2012) Growth factor-extracellular matrix interactions regulate wound repair. Adv Wound Care (New Rochelle) 1: 249-254.

Wu Y, Huang F, Zhou X, Yu S, Tang Q, Li S, Wang J, Chen L (2016) Hypoxic preconditioning enhances dental pulp stem cell therapy for infection-caused bone destruction. Tissue Eng Part A 22: 1191-1203.

Xie L, Mao M, Zhou L, Zhang L, Jiang B (2017) Signal factors secreted by 2D and spheroid mesenchymal stem cells and by cocultures of mesenchymal stem cells derived microvesicles and retinal photoreceptor neurons. Stem Cells Int 2017: 2730472. DOI: $10.1155 / 2017 / 2730472$.

Xue J, Gong Y, Zhou G, Liu W, Cao Y, Zhang W (2012) Chondrogenic differentiation of bone marrowderived mesenchymal stem cells induced by acellular cartilage sheets. Biomaterials 33: 5832-5840.

Yano F, Hojo H, Ohba S, Saito T, Honnami M, Mochizuki M, Takato T, Kawaguchi H, Chung UI (2013) Cell-sheet technology combined with a thienoindazole derivative small compound TD198946 for cartilage regeneration. Biomaterials 34: 5581-5587.

Yorukoglu AC, Kiter AE, Akkaya S, SatirogluTufan NL, Tufan AC (2017) A concise review on the use of mesenchymal stem cells in cell sheet-based tissue engineering with special emphasis on bone tissue regeneration. Stem Cells Int 2017: 2374161. DOI: 10.1155/2017/2374161.

Young DA, Choi YS, Engler AJ, Christman KL (2013) Stimulation of adipogenesis of adult adiposederived stem cells using substrates that mimic the stiffness of adipose tissue. Biomaterials 34: 8581-8588.
Zeiger AS, Loe FC, Li R, Raghunath M, Van Vliet KJ (2012) Macromolecular crowding directs extracellular matrix organization and mesenchymal stem cell behavior. PLoS One 7: e37904. DOI: 10.1371/ journal.pone.0037904.

Zeitouni S, Krause U, Clough B, Halderman H, Falster A, Blalock D, Chaput C, Sampson H, Gregory C (2012) Human mesenchymal stem cell-derived matrices for enhanced osteoregeneration. Sci Transl Med 4: 132ra155. DOI: 10.1126/scitranslmed.3003396.

Zhang Y, Li J, Davis M, Pei M (2015) Delineation of in vitro chondrogenesis of human synovial stem cells following preconditioning using decellularized matrix. Acta Biomater 20: 39-50.

Zhao C, Jiang W, Zhou N, Liao J, Yang M, Hu N, Liang X, Xu W, Chen H, Liu W, Shi L, Oliveira L, Wolf J, Ho S, Athiviraham A, Tsai H, He T, Huang W (2017) Sox9 augments BMP2-induced chondrogenic differentiation by downregulating Smad7 in mesenchymal stem cells (MSCs). Genes Dis 4: 229-239.

Zhao Q, Eberspaecher H, Lefebvre V, De Crombrugghe B (1997) Parallel expression of Sox9 and Col2a1 in cells undergoing chondrogenesis. Dev Dyn 209: 377-386.

Zheng Q, Zhou G, Morello R, Chen Y, GarciaRojas X, Lee B (2003) Type X collagen gene regulation by Runx2 contributes directly to its hypertrophic chondrocyte-specific expression in vivo. J Cell Biol 162: 833-842.

Zohar R, Cheifetz S, McCulloch CA, Sodek J (1998) Analysis of intracellular osteopontin as a marker of osteoblastic cell differentiation and mesenchymal cell migration. Eur J Oral Sci 106 Suppl 1: 401-407.

Zou XH, Cai HX, Yin Z, Chen X, Jiang YZ, Hu H, Ouyang HW (2009) A novel strategy incorporated the power of mesenchymal stem cells to allografts for segmental bone tissue engineering. Cell Transplant 18: $433-441$.

Editor's note: There were no questions asked by reviewers for this paper, therefore, there is no Discussion with Reviewers section. The Scientific Editor responsible for this paper was Martin Stoddart. 